\title{
Bi-Sn-Mo-W greisen mineralization associated with the True Hill granite, southwestern New Brunswick
}

\author{
David R. Lentz \\ Ottawa-Carleton Geoscience Center, University of Ottawa, Ottawa, Ontario K1N 6N5 \\ Glenn Lutes \\ Project Geologist, FinNeth Exploration Incorporated, 97 Emmerson Street \\ Fredericton, New Brunswick E3B 6A8 \\ and \\ Ron Hartree \\ Ottawa-Carleton Geoscience Center, University of Ottawa, Ottawa, Ontario K1N 6NS
}

Date Received May 30, 1988

Date Accepted August 26, 1988

\begin{abstract}
The Devono-Carboniferous True Hill subvolcanic granite porphyry in southwestern New Brunswick forms three granite cupolas along a northeasterly trend. It intruded greenschist-facies argillites of Silurian age, and contains K-feldspar, quartz, plagioclase and biotite phenocrysts in a fine-grained, hypidiomorphic to allotriomorphic granular matrix of similar mineralogy. Metasedimentary xenoliths, narrow metamorphic aureoles along intrusive contacts, miarolitic cavities, pegmatite pods and granophyric texture attest to the upper epizonal nature of the granite. Geochemical constraints indicate a temperature of crystallization of $700^{\circ} \mathrm{C}-730^{\circ} \mathrm{C}$, at $100 \mathrm{MPa}$ and less than $1 \mathrm{wt} . \%$ fluorine. The True Hill granite is chemically similar to other granites in the Beech Hill series, including the Mount Pleasant fine-grained granite, and to portions of the Eastern Saint George granite batholith. The True Hill granite is weakly peraluminous ( $\mathrm{A} / \mathrm{CNK}=1.6)$ with a high silica $(76.6 \mathrm{wt} . \%)$ content.

Bi-Sn-Mo-W mineralized zones associated with the cupolas of the True Hill granite are mineralogically similar to but less well developed than W-Mo-Bi mineralization associated with the fine-grained Mount Pleasant granite and the fine-grained portion of the Eastem Saint George granite batholith. Feldspathic alteration is developed locally in the deeper portions of the True Hill granite, but is inconspicuous in the more intensely altered cupola. Alteration in the cupola includes pervasive and vein quartz-topaz-sericite greisen, quartz-sericite greisen, and quartz-chlorite-sericite greisen in weakly-altered granite. The first two types of greisen contain wolframite $(\mathrm{W}=10-60 \mathrm{ppm})$, molybdenite $(\mathrm{Mo}=5-100 \mathrm{ppm})$ and bismuthinite $(\mathrm{Bi}=5->10,000 \mathrm{ppm})$ with low $\mathrm{Sn}$, whereas the third contains cassiterite $(\mathrm{Sn}=30-300 \mathrm{ppm})$ minor pyrite, magnetite and rarely hematite with low $\mathrm{Bi}$, Mo and W. All types of alteration contain fluorite $(0.3->2.0 \mathrm{wt} . \% \mathrm{~F})$. The exogranitic alteration and mineralization is more complex than granite-hosted mineralized zones due to strong compositional control of the metasedimentary rocks on the greisen assemblages.
\end{abstract}

Le porphyre granitique subvolcanique dévono-carbonifere de True Hill forme au sud-ouest du Nouveau-Brunswick trois coupoles de granites alignées nord-est. Il recoupe des argilites siluriennes du faciès schistes-verts et montre des phénocristes de feldspath-K, quartz, plagioclase et biotite sis au sein d'une fine matrice grenue, hypidiomorphe à allouriomorphe, de minér alogie similaire. Des xénolites métasédimentaires, d'étroites auréoles métamorphiques le long des contacts intrusifs, des cavités miarolitiques, des venues pegmatitiques et une texture granophyrique dénotent la nature épizonale haute du granite. Les paramètres géochimiques indiquent une température de cristallisation de $700^{\circ} \mathrm{C}-730^{\circ} \mathrm{C}$ à $100 \mathrm{MPa}$ et moins de $1 \%$ pds de fluor. Le granite de True Hill rappelle par son chimisme les autres granites de la série de Beech Hill, le granite à grain fin de Mount Pleasant et des portions de l'Est du batholite granitique de Saint George. Il est faiblement péralumineux $(\mathrm{A} / \mathrm{CNK}=1.6)$ avec un contenu élevé en silice ( $76.6 \%$ pds.).

Les zones minéralisées en $\mathrm{Bi}$-Sn-Mo-W associées aux coupoles du granite de True Hill présentent une minéralogie analogue mais sont moins bien développées que les minéralisations en W-Mo-Bi associées au granite à grain fin de Mount Pleasant et à la fraction fine de l'Est du batholite granitique de Saint George. Il y a développement local d'une altération feldspathique dans les tréfonds du granite de True Hill quoiqu'elle passe inaperçue dans les coupoles plus altérées. L'altération comprend des greisens pénétrants et en veines à quartz-topaze-séricite, des greisens à quartz-séricite dans les coupoles ainsi que des greisens à quartz-chlorile-séricite dans le granite faiblement altéré. Les deux premiers types de greisen renferment de la wolframite (W 
$=10-60 \mathrm{ppm})$, de la molybdénite $(\mathrm{Mo}=5-100 \mathrm{ppm})$ et de la bismuthinite $(\mathrm{Bi}=5->10,000 \mathrm{ppm})$ avec quelque $\mathrm{Sn}$, alors que le troisième contient de la cassitérite $(\mathrm{Sn}=30-300 \mathrm{ppm})$, un peu de pyrite, de magnétite et, rarement, d'hématite avec quelque $\mathrm{Bi}$, Mo et $\mathrm{W}$. Tous ces types d'altération contiennent de la fluorine $(0.3->2.0 \% \mathrm{~F})$. L'altération et la minéralisation exogranitiques sont plus complexes que les zones minéralisées au sein du granite à cause du contrôle strict exercé par les roches métasédimentaires sur les assemblages de greisens.

[Traduit par le journal]

\section{INTRODUCTION}

This study of the True Hill granite and associated mineralization was undertaken to determine the nature and source of the granophile mineralization and greisen alteration. An integral part of the study is a petrological and geochemical comparison of the mineralized zones at True Hill with published information on similar mineralization elsewhere in southwestern New Brunswick, particularly the Mount Pleasant ore bodies.

True Hill is located along the northern margin of the Saint George batholith in southwestern New Brunswick (Fig. 1) and is underlain by a subvolcanic granite porphyry intrusion. The True Hill intrusion is genetically related to the Beech Hill, Sorrel Ridge, and Mount Pleasant granites, based on similar ages and chemical composition (Dagger, 1972; Butt, 1976) (Fig. 2). A number of Sn-W-Mo-Bi deposits were formed in association with these weakly peraluminous granites (Ruitenberg and Fyffe, 1982), of which the largest is the W-Mo-Bi deposit at Mount Plcasant.

In the first part of this paper, the petrographic and chemical features of the True Hill granite are presented. The second part describes the weakly mineralized $\mathrm{Bi}-\mathrm{Sn}-\mathrm{Mo}-\mathrm{W}$ zones associated with the True Hill granite, and the W-Mo-Bi orebody related to the fine-grained Mount Pleasant granite. Finally, a model is prcsented to explain the present distribution of the Sn-W-Mo-Bi mineralization associated with these fine-grained porphyritic intrusions.

\section{GEOLOGIC SETTING}

The Saint George batholith and marginal stocks of the Beech Hill series (including the Mount Pleasant fine-grained granite and the True Hill, Beech Hill, Pleasant Ridge and Sorrel Ridge granites) intruded feldspathic graywackes and argillites of the Silurian Waweig Formation along the northern margin of the batholith (Ruitenberg et al., 1977; Ruitenberg and McCutcheon, 1982). During the Acadian Orogeny, these rocks were metamorphosed to lower greenschist facies and, proximal to intrusions, to andalusite-cordierite hornfels facies (Ruitenberg and McCutcheon, 1982).

Three dominant fold generations and two prominent cleavages were developed in the metasedimentary rocks (Ruitenberg, 1972). Early folds are tight upright and have shallow northeasterly plunges. The latest episodes of the Acadian Orogeny formed northeast-striking thrusts which terminate against northweststriking wrench faults (Ruitenberg and McCutcheon, 1982). During the Hercynian Orogeny, northeast- and northwest-trending faults were reactivated during volcanic activity (Ruitenberg and McCutcheon, 1982). The Tower Hill, Sorrel Ridge and
Beech Hill granites seems to have been emplaced along the St. David's domal structure which is offset by the later wrench faulting (Dagger, 1972).

The Mount Pleasant mine is located along the southwestern margin of the Mount Pleasant caldera which consists of shallowly dipping, dominantly felsic volcanic and sedimentary rocks (Ruitenberg and McCutcheon, 1985). To the north of the Mount Pleasant caldera, sandstone, and conglomerate of the Upper Mississippian to Pennsylvanian Hopewell Group disconformably overlie the volcanic rocks.

The Saint George batholith is a post-Acadian, bimodal gabbroic-granite suite (Cherry, 1976). The Late Devonian (Carboniferous?) Eastern Saint George batholith (Mt. Douglas granite) is compositionally similar to the older biotite granite (406 $\pm 7 \mathrm{Ma}$ ); (Cherry, 1976; Fyffe et al., 1981) of the Western Saint George batholith and to the Beech Hill series of marginal granite intrusions (Butt, 1976; Ruitenberg and Fyffe, 1982). The $\mathrm{Rb}-\mathrm{Sr}$ whole-rock age of $345 \pm 8 \mathrm{Ma}$ for the Eastem Saint George batholith is statistically inseparable from the $337 \pm 15 \mathrm{Ma}$ age of the Beech Hill intrusion (Fyffe et al., 1981) and the 332 $+12 \mathrm{Ma}$ age for several of the granites from the Mount Pleasant granite suite (Kooiman et al., 1986). These Rb-Sr dates agree well with potassium-argon ages ( $334 \pm 7 \mathrm{Ma}$ and $339 \pm 10 \mathrm{Ma}$ ) obtained from the Mount Pleasant biotite granite porphyry (Kooiman et al., 1986). However, more recent ${ }^{40} \mathrm{Ar} /{ }^{9} \mathrm{Ar}$ step heating of mineralized samples from the Eastern Saint George granite yielded ages of $367 \mathrm{Ma}$, suggesting a more protracted intrusive history (McLeod et al., in press; McLeod, 1988).

Previous studies have shown that granites of the Beech Hill series are peraluminous and characterized by $74-78 \mathrm{wt} . \% \mathrm{SiO}_{2}$, high $\mathrm{K}_{2} \mathrm{O} / \mathrm{Na}_{2} \mathrm{O}$ ratios (1.2-2.2) and $\mathrm{Rb} / \mathrm{Sr}$ ratios (6-48) and low $\mathrm{CaO}$ (0.04-0.60 wt.\%), $\mathrm{TiO}_{2}(0.04-0.25$ wt.\%) and $\mathrm{Zr}$ (11-162 ppm) (Ruitenberg and Fyffe, 1982; Butt, 1976; Dagger, 1972) (see Table 1). They have a very high initial ${ }^{87} \mathrm{Sr} /{ }^{86} \mathrm{Sr}$ ratio (0.7186 \pm 0.0010 ; L. Fyffe, personal communication, 1985), comparable with the Mount Pleasant granites $(0.7133 \pm 0.0062$; Kooiman et al., 1986) but markedly different from the initial strontium ratio of 0.7045 of the Eastern Saint George granite batholith (L. Fyffe, personal communication, 1985). The Beech Hill granite series of intrusions have $\delta^{18} \mathrm{O}$ values between +8 and +9\% (Taylor et al., 1985), indicating minor assimilation of sedimentary crustal material and negligable meteoric water during the genesis of these granites.

Crystallization of the groundmass of the Beech Hill granite and the Eastern Saint George granite batholith was interpreted to have occurred near the granite-minimum temperature $\left(730^{\circ} \mathrm{C}\right)$ at $\mathrm{P}\left(\mathrm{H}_{2} \mathrm{O}\right)=100.0 \pm 50.0 \mathrm{MPa}$ (Butt, 1976; Cherry, 1976). For the groundmass of the compositionally similar Early Devonian portion of the Western Saint George batholith, the crystallization condi- 


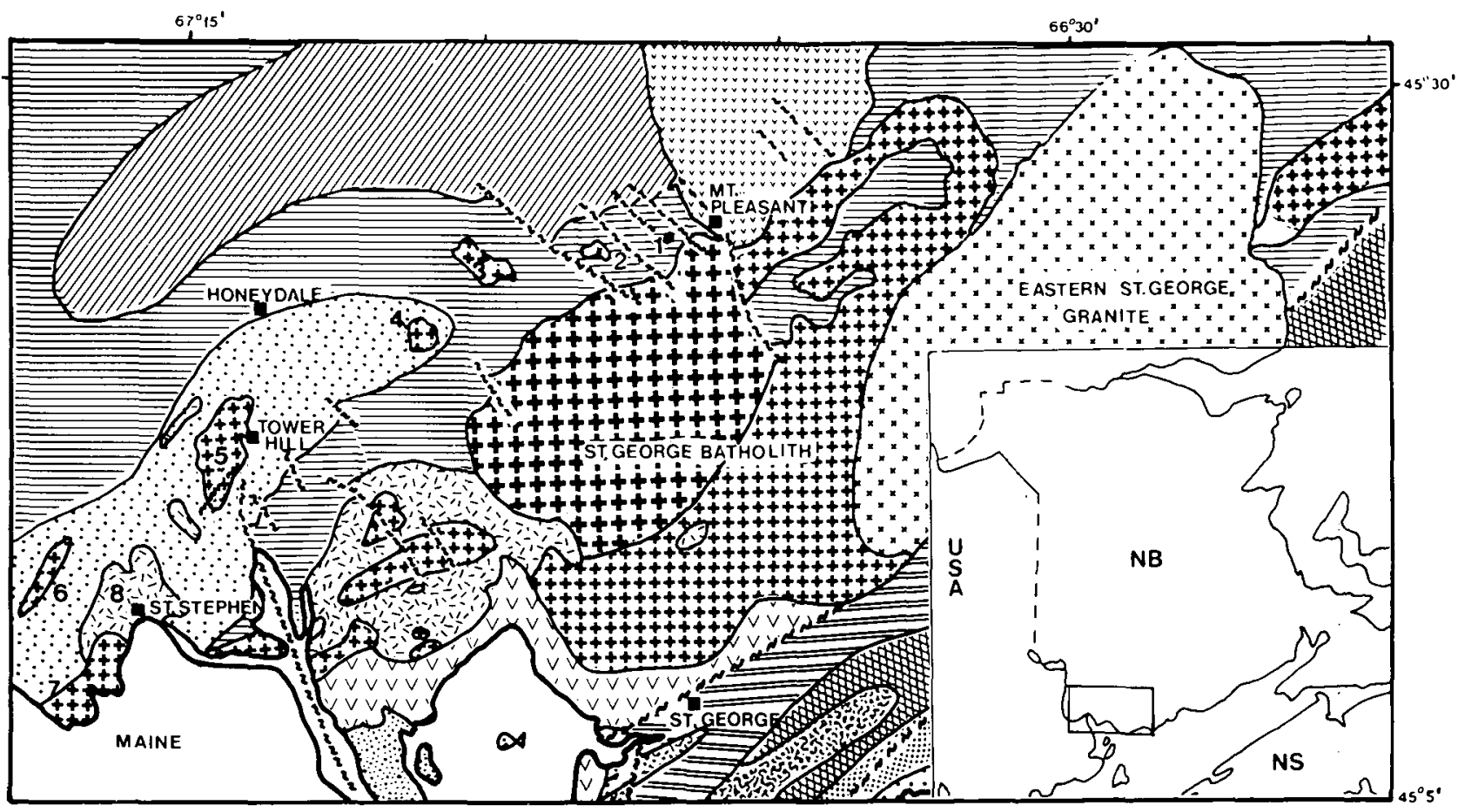

MISSISSIPPIAN

LEGEND

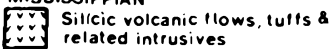

\# Granite line grained porphyritic to

DE VONIAN

Red conglomerate. sandstone. 8
shale

Fin Granite, adamellite, 8 minor

24 granodiorite; Megacrystic granite

$\therefore$ Gabbro, diabase diorite

Cataclastic to migmatitic granitic

to dioritic rock

Rnyolite, trachyte 8 related

DE VON IANAND SILUAIAN

Draywacke.sandstone.conglomerate 8

A minor volcanics

Rige日 Rolite.trachyte iult \& related

Fin intrusions

SILURIAN

Greywacke. slates, siltstone.8

sandstone

$\Rightarrow$ Rhyolite. trachyte.8 related

intrusions

ORDOVICIAN

$\therefore$ Argillaceous sediments.grarwacke

:] quartzite, conglomerate

PRECAMBRIAN

E:. Granite granodiorite diorite

gneisses

Sedimentary \& volcanic rocks.metamor phic equivalents

$x$ undifterentialed intrusions

1 TRUE HILL STOCK

2 BEECH HILL STOCK

3 PLEASANT RIDGE STOCK

4 SORREL RIDGE STOCK

5 TOWER HILL STOCK

GMOHANNAS STOCK

7 MILLTOWN GRANITE

BST.STEPHEN GABBRO

FAULT

GEOLOGICAL MAP OF

SOUTHWESTERN NEW BRUNSWICK

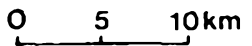

(modified after BUIT 1976)

Fig. 1. Geological map of southwestem New Brunswick (after Buth 1976). 


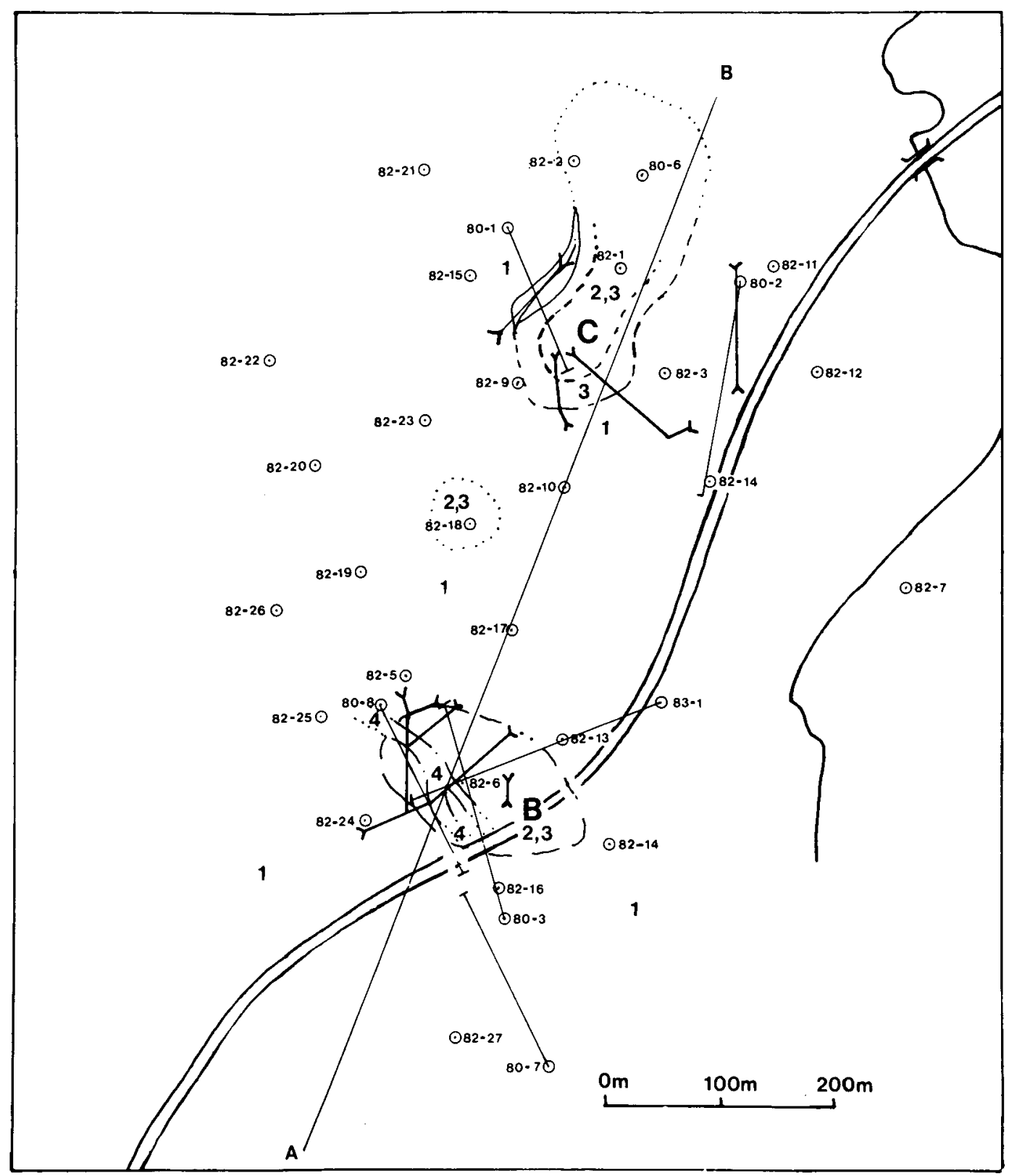

Fig. 2. True Hill geologic map of cupola $B$ and $C$ with diamond-drill-hole (DDH) and trench locations: 1 - Metasedimentary rocks, 2 - Granite Porphyry, 3 - Greisenization, 4 - Tin-sulfide lodes.

(A-B cross-section, see Fig. 3)

tions were $\mathrm{T}<715^{\circ} \mathrm{C}$ and $\mathrm{P}\left(\mathrm{H}_{2} \mathrm{O}\right)=100-200 \mathrm{MPa}$ (Cherry, 1976). Butt (1976) attributed the variations in major, trace and volatile elements in the Beech Hill stock to filter-pressing, vapour-phase separation and deuteric alteration which caused the depletion and/or redistribution of elements (Butt, 1976).

The fine-grained granite beneath the W-Mo-Bi orebody at Mount Pleasant is petrographically and geochemically similar to the Beech Hill, True Hill, and Sorrel Ridge granites (Butt, 1976; Dagger, 1972). The W-Mo-Bi mineralization at Mount Pleasant is also mineralogically and compositionally similar to but more intensely developed than that found in the apical portions of the True Hill and Beech Hill granites. At Beech Hill, mineralization is mainly restricted to the contact aureole of the intrusion whereas it is found in cupolas of the True Hill and the Mount Pleasant intrusions.

\section{TRUE HILL GRANITE}

\section{Contact Relationships}

Metasedimentary units in the True Hill area trend northeast and have moderate dips to the north; a weakly developed, subvertical fracture cleavage trending east-west occurs locally. The granite has three exposed cupolas (A, B, and C), two of which are greisenized (B and C) (Figs. 2, 3). The southern contact between the metasedimentary units and the granite porphyry dips gently south. In contrast, the northern contact dips $45^{\circ} \mathrm{N}$ according to drill-hole data (Lutes, unpublished data).

Hornfels is not extensive in the metasedimentary rocks due to the small size of the granite and its shallow level of emplacement. The assemblage near the contact consists of biotite- 
Table 1. Whole rock chemical analyses of granite samples* from True Hill, as well as average chemical analyses from True Hill (TH) (Dagger, 1972), Beech Hill (BH)(Butt, 1976), Eastern Saint George batholith (ESGB)(Cherry, 1976), Sorrel Ridge (SR)(Butt, 1976), and Mount Pleasant (MP)(Kooiman et al., 1986).

\begin{tabular}{|c|c|c|c|c|c|c|c|c|c|c|c|c|c|c|c|c|c|c|}
\hline Sample & $\begin{aligned} & 3-465 \\
= & ==-=\end{aligned}$ & $\begin{aligned} & 3 \cdots 690 \\
== & ===\end{aligned}$ & $\begin{aligned} & 3-970 \\
== & ====\end{aligned}$ & $\begin{aligned} & 6-845 \\
=z= & == \pm=\end{aligned}$ & $\begin{array}{c} \\
6-8 \% \\
===-==-=\end{array}$ & 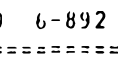 & $\begin{aligned} & 6-925 \\
&==-\approx==-=\end{aligned}$ & $\begin{aligned} & 6-1011 \\
&==-===-=\end{aligned}$ & $\begin{aligned} & 6-1285 \\
==== & ==\end{aligned}$ & $\begin{array}{c}6-1300 \\
======\end{array}$ & $\begin{array}{l}\text { TH } 111 \\
=:====\end{array}$ & $\begin{array}{l}11=31 \\
==-===2\end{array}$ & $\begin{aligned} & \text { BH }(n \\
&===-==-=\end{aligned}$ & $\begin{array}{l}=161 \\
=====\end{array}$ & $\begin{array}{l}\text { FSGB } \\
=====0\end{array}$ & $\begin{array}{l}(n=1 \%) \\
== \pm====\end{array}$ & $\begin{array}{l}\text { SK }(n=3) \\
== \pm= \pm==== \pm=\end{array}$ & $\begin{array}{l}\text { MP } \\
===\end{array}$ \\
\hline $\sin ($ (wt. 8 ) & 76.36 & 77.73 & 76.34 & 76.47 & 76.02 & 77.65 & 77.23 & 77.79 & 76.33 & 65.15 & $76.22=$ & $?=0.14$ & $75.19=$ & $=2.81$ & 76.94 & $=1.17$ & $73.98=1.63$ & 75.70 \\
\hline Ti02 & 0.09 & 0.08 & 0.08 & 0.07 & 0.11 & 0.10 & 0.10 & 0.08 & 0.07 & 0.26 & $0.07=$ & $=0.02$ & $0.23=$ & $=0.10$ & 0.18 & $=0.06$ & $0.25=0.09$ & 0.04 \\
\hline A1203 & 12.39 & 12.81 & 12.53 & 12.76 & 12.37 & 12.35 & 12.44 & 12.43 & 12.61 & 17.15 & $13.53=$ & $3=0.11$ & $12.72=$ & $=0.75$ & 12.40 & $=0.37$. & $12.48=0.42$ & 12.90 \\
\hline $\mathrm{Fe} 203$ & 1.63 & 1.59 & 0.93 & 0.79 & 0.57 & $1.3 \%$ & 1.39 & 1.06 & 1.16 & 3.53 & $1.34=$ & $1=0.11$ & $0.98=$ & $=0.38$ & 0.30 & $=0.18$ & $0.57=0.40$ & 0.30 \\
\hline $\mathrm{FeO}$ & NA & NA & $\mathrm{NA}$ & NA & NA & NA & NA & NA & NA & NA & & NA & $0.77=$ & $=0.43$ & 0.90 & $=0.28$ & $0.96=0.32$ & 1.20 \\
\hline Mno & 0.08 & 0.08 & 0.03 & 0.03 & 0.03 & 0.05 & 0.08 & 0.04 & 0.04 & 0.20 & $0.03=$ & $=0.00$ & $0.04=$ & $=0.03$ & 0.02 & $=0.01$ & $0.02=0.01$ & 0.13 \\
\hline MgO & 0.28 & 0.80 & 0.13 & 0.11 & 0.04 & 0.07 & 0.28 & 0.20 & 0.11 & 0.27 & $0.23=$ & $=0.10$ & $0.25=$ & $=0.13$ & $0.17=$ & $=0.02$ & $0.22=0.12$ & 0.79 \\
\hline$c$ & 0.52 & 0.63 & 0.48 & 0.53 & 0.72 & 0.64 & 0.54 & 0.57 & 0.54 & 0.14 & $0.52=$ & $=0.17$ & $0.60=$ & $=0.32$ & $0.64=$ & $=0.32$ & $0.45=0.14$ & 0.03 \\
\hline $\mathrm{Na} 2 \mathrm{O}$ & 2.67 & 1.71 & 2.49 & 2.78 & 1.70 & 2.64 & 2.90 & 3.00 & 3.19 & 3.63 & $3.14=$ & $=0.30$ & $3.68=$ & $=0.55$ & $3.31=$ & $=0.18$ & $3.08=0.25$ & 3.50 \\
\hline K 20 & 5.29 & 5.18 & 5.33 & 5.39 & 5.18 & 5.15 & 5.22 & 4.56 & 5.48 & 8.21 & $4.91=$ & $=0.09$ & $4.31=$ & $=1.01$ & $5.09=$ & $=0.26$ & $4.67=0.35$ & 4.98 \\
\hline 05 & 0.03 & 0.01 & 0.01 & 0.00 & 0.01 & 0.03 & 0.01 & 0.01 & 0.02 & 0.00 & & NA & $0.05=$ & $=0.02$ & $0.04=$ & $=0.02$ & $0.04=0.02$ & 0.00 \\
\hline LOI & 1.08 & 1.40 & 0.59 & 0.99 & 1.50 & 0.79 & 0.94 & 1.04 & 0.99 & 1.08 & & NA & NA & A & & va & NA & 0.00 \\
\hline Total & 100.42 & 102.02 & 98.94 & 99.92 & 98.25 & 100.84 & 101.13 & 100.78 & 100.54 & 99.92 & 99.99 & & 98.82 & & 9.99 & & 6.72 & 99.57 \\
\hline$F$ (wt. 8 ) & 0.30 & 0.36 & 0.29 & 0.46 & 44 & .63 & 34 & .29 & 0.30 & 0.13 & & NA & NA & A & & AA & NA & 0.48 \\
\hline$S$ (wt. .8 ) & 0.19 & 0.01 & 0.01 & 0.00 & 0.01 & 0.00 & 0.01 & 0.00 & 0.01 & 0.15 & & NA & NA & A & & va & NA & NA \\
\hline $\mathrm{Ba}(\mathrm{ppm}$ & 145 & 134 & 144 & 111 & 141 & 110 & 191 & 125 & 95 & 127 & & NA & $128=$ & $=205$ & & VA & $312=194$ & 40 \\
\hline $\mathrm{Cr}$ & 0 & 0 & 2 & 0 & 0 & 8 & 0 & 5 & 0 & 9 & & NA & NA & A & & va & NA & 0 \\
\hline $2 x$ & 133 & 124 & 128 & 124 & 164 & 146 & 145 & 139 & 123 & 12 & $145=$ & $=16$ & $162=$ & $=95$ & $121=$ & $=31$ & $110=46$ & 141 \\
\hline$S_{r}$ & 21 & 8 & 15 & 15 & 23 & 14 & 21 & 13 & 17 & 24 & $23=$ & $=4$ & $60=$ & $=32$ & $35=$ & $=37$ & 42 & 13 \\
\hline$R b$ & 523 & 559 & 584 & 636 & 613 & 622 & 572 & 588 & 620 & 1065 & & $=79$ & $403=$ & $=99$ & $364=$ & $=73$ & $104=43$ & 625 \\
\hline Y & 95 & 73 & 81 & 119 & 110 & 114 & 79 & 122 & 152 & 20 & $83=$ & $=13$ & NA & A & & A & NA & 0 \\
\hline Nb & 39 & 61 & 62 & 51 & 37 & 43 & 41 & 43 & 59 & 104 & $100=$ & $=33$ & NA & A & & IA & NA & 92 \\
\hline $2 r$ & 135 & 62 & 46 & 68 & 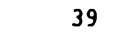 & 15 & 72 & 65 & 48 & 77 & $81=$ & $=32$ & $47=$ & $=28$ & & IA & $54=21$ & 52 \\
\hline $\mathrm{Ni}$ & 23 & 15 & 13 & 19 & 20 & 106 & 11 & 11 & 31 & 17 & & va & $10=$ & $=8$ & & IA & $<1$ & 0 \\
\hline v & 0 & 4 & 0 & 4 & 0 & 3 & 9 & 0 & 0 & 0 & & NA & $19=$ & $=12$ & & IA & NA & 0 \\
\hline y & 39.14 & 45.44 & 40.26 & 38.37 & 44.73 & 41.19 & 84 & 40 & 4 & 11. & & 37.71 & & 35 & & 36.17 & 36 & 34.07 \\
\hline or & 31.26 & 30.61 & 50 & 31.85 & 30.61 & 30.44 & & & & & & & & & & & & 43 \\
\hline$a b$ & 22.59 & 14.47 & 21.07 & 23.52 & 14.39 & 22.34 & 24.54 & 25.39 & 26.99 & 30.72 & & 26.57 & & 31.14 & & 28.01 & 26.06 & 29.62 \\
\hline an & 2.38 & 3.06 & 2.32 & 2.63 & 3.51 & 2.98 & 2.61 & 2.76 & & 2.18 & & 2.58 & & 2.65 & & 2.91 & 1.97 & 0.15 \\
\hline$c$ & 1.40 & 3.27 & 1.82 & 1.39 & 2.68 & 1.34 & 1.06 & 1.55 & 0.50 & 1. & & 2.10 & & 1.03 & & 0.38 & 1.64 & 1.70 \\
\hline hy & & 1.99 & & 0. & 0 . & & & 0 . & 0. & 0. & & 0.57 & & 0.92 & & 1.57 & 1.46 & 4.10 \\
\hline$m t$ & 0.00 & 0.03 & 0.00 & 0.00 & 0.00 & 0.00 & 0.00 & 0.00 & 0.00 & 0.00 & & 0.00 & & 1.12 & & 0.43 & 0.83 & 0.43 \\
\hline 11 & 0.17 & 0.15 & & 0.06 & & & & 0.09 & 0.09 & & & 0.06 & & 0.44 & & 0.34 & 0.47 & 0.08 \\
\hline hem & 1.63 & 1.57 & 0.93 & 0.79 & 0.57 & 1.37 & 1.39 & 1.06 & 1.16 & 0.00 & & 1.34 & & 0.00 & & 0.00 & 0.00 & 0.00 \\
\hline ap & 0.07 & 0.02 & 0.02 & 0.0 & 0.02 & 0.07 & 0.02 & 0.02 & 0.05 & 0.1 & & 0.00 & & 0.12 & & 0.09 & 0.09 & 0.00 \\
\hline ru & 0.00 & 0.02 & 0.05 & 0.04 & 0.08 & 0.04 & 0.01 & 0.03 & 0.02 & 0.00 & & 0.04 & & 0.00 & & 0.00 & 0.00 & 0.00 \\
\hline$F / F+$ & 0.85 & .65 & 0.87 & 0.87 & 0.93 & 0.95 & 0.83 & 0.83 & 0.91 & 0.93 & & 0.84 & & 0.87 & & 0.88 & 0.87 & 0.67 \\
\hline $\mathrm{Rb} / \mathrm{Sr}$ & 24.91 & 69.88 & 38.93 & 42.40 & 26.65 & 14.43 & 27.24 & 45.23 & 36.47 & 14. & & 21.22 & & 6.72 & & 10.40 & 9.62 & 48.08 \\
\hline $\mathrm{K} / \mathrm{Rb}$ & 84.00 & 77.00 & 76.00 & 70.00 & 70.00 & 69.00 & 76.00 & 64.00 & 73.00 & 64.00 & & 84.00 & & 89.00 & & 116.00 & 96.00 & 66.00 \\
\hline$K / B a$ & 302.80 & 320.90 & 307.20 & 403.00 & 304.90 & 388.60 & 226.80 & 302.80 & 178.80 & 536.60 & & 0.00 & & 83.60 & & 0.00 & 124.20 & 1033.40 \\
\hline
\end{tabular}

*Sample numbers indicate drill hole number and footage.

Analytical Techniques:

$\mathrm{X}$-ray fluorescence (Phillips PW140) analyses of major- and trace-elements were performed on fused disks $\left(\mathrm{Li}_{2} \mathrm{CO}_{3}+\mathrm{Li}_{2} \mathrm{~B}_{4} \mathrm{O}_{7}+\right.$ sample) (at the University of Ottawa). SY-2 was used as the internal standard for determining accuracy and precision (Abbey, 1983). Estimates of precision for the major elements are less than $2 \%$ except for $\mathrm{Na}_{2} \mathrm{O}(<8 \%)$, and for trace elements is $5 \%$ except for the very low abundance elements $(50 \%)$. Loss on Ignition (LOI) represents the weight loss after heating in a muffle furnace at $1050^{\circ} \mathrm{C}$ for 2 hrs. The LOI may include some $\mathrm{F}$ and $S$ which have been analysed separately resulting is slightly high totals. Sulfur and fluorine were determined by Dionex HPLC (High Pressure Liquid Chromatography) at the Geological Survey of Canada; duplicate analyses and standards indicate less than $20 \%$ error. 


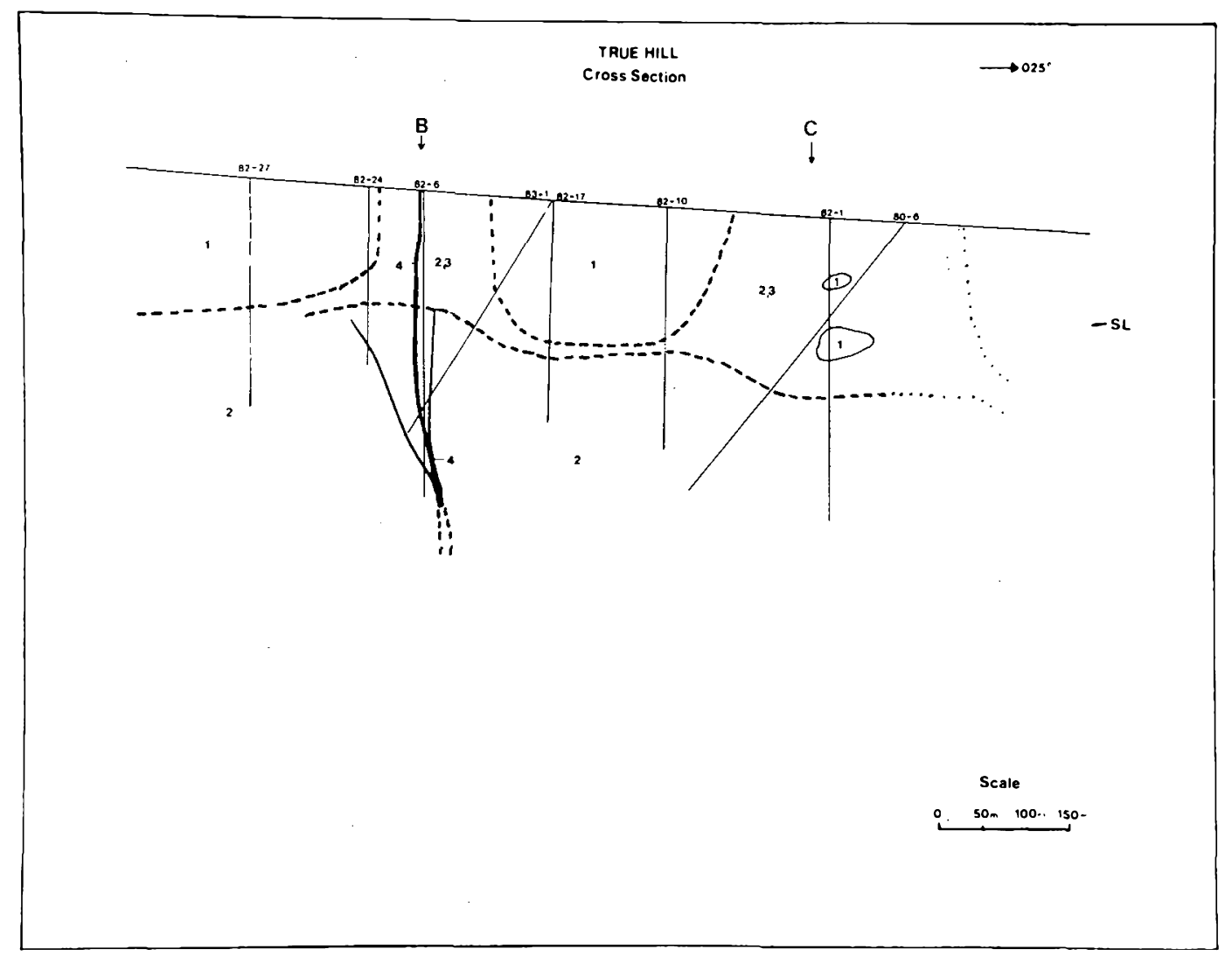

Fig. 3. Geological cross-section of cupola B and C (see Fig. 2 for legend).

andalusite-cordierite with muscovite and quartz, indicating medium grade contact metamorphism. Andalusite porphyroblasts were observed up to $120 \mathrm{~m}$ from the inferred contact of the granite.

The nature of the contact between the granite porphyry and the metasedimentary rocks is variable. Intrusive contact-breccias (homfelsic metasedimentary breccia in an aplitic matrix) occur in cupola B, suggesting either faulted contacts or brecciation during intrusion. Hydrothermal pebble-breccia is very well developed in cupola $\mathrm{C}$ where the breccia conforms to the granitemetasedimentary rock contact which dips approximately $60^{\circ}$ to the northwest at surface. Breccia fragments include altered metasedimentary rocks and granite porphyry in a siliceous, nuorite-bearing matrix. The angularity of the pebbles is variable and clast size increases toward and into the granite which suggests intensive hydrofracturing. Numerous rebrecciated fragments indicate pulsing of the venting hydrothermal solutions. Intense sericitization and silicification of fragments also resulted from the venting of these fluids. Extensive quartz veining and silicification is commonly associated with the contact between the granite porphyry and the metasedimentary rocks. Quartz veins locally have sericite-, K-feldspar- and/or biotite-rich selvages and in places contain minor fluorite and pyrite. Hybrid granite is developed at more "passive" contacts, with biotite schlieren (up to $10 \mathrm{vol} . \%$ biotite) developed within a meter of the contact.

\section{Petrography}

The True Hill granite is hiatal porphyritic, with equal proportions of quartz and $\mathrm{K}$-feldspar phenocrysts and variable amounts of biotite and plagioclase. Quartz and K-feldspar phenocrysts range in size from $1 \mathrm{~mm}$ to $2 \mathrm{~mm}$ on average and have euhedral to subhedral morphology. The K-feldspar contains various styles of exsolution (string and patch perthite) and intergrowth with and/or replacement by plagioclase. Plagioclase also forms euhedral phenocrysts which are commonly finer grained than the dominant phases. Biotite is fine grained $(0.5$ $\mathrm{mm}$ ) and contains zircon, sphene, opaque phases and rare cassiterite. The groundmass usually has granophyric quartz and $\mathrm{K}$ feldspar intergrowths near miarolitic cavities and pegmatite pods that probably reflect local $\mathrm{H}_{2} \mathrm{O}$ saturation (second boiling/resurgent boiling) typical of epizonal intrusions.

Rapid intrusion of a phenocryst-bearing magma into cooler country rock promotes diffusional loss of heat and vapour phase separation which may supercool a magma up to $30^{\circ} \mathrm{C}$ (Burnham, 1979). Both lead to crystallization of the magma and the development of porphyritic texture, but second boiling readily explains all the petrographic features in the True Hill granite. Cherry (1976) also concluded that vapour phase loss was critical in the development of the porphyritic granites in the Eastern Saint George batholith and that rapakivi texture, commonly associated with the fine-grained granite, probably resulted from $\mathrm{H}_{2} \mathrm{O}$ pressure quenching of the magma (Cherry and Trembath, 1978). 


\section{Chemical Composition}

The True Hill granite has high $\mathrm{SiO}_{2}(76.9$ wt.\%) with low $\mathrm{MgO}\left(0.22\right.$ wt.\%) and $\mathrm{Fe}_{2} \mathrm{O}_{3}(\mathrm{~T})(1.44$ wt.\%) (Table 1). It has very low $\mathrm{CaO}$, moderate $\mathrm{Na}_{2} \mathrm{O}(2.25 \mathrm{wt} . \%)$ and high $\mathrm{K}_{2} \mathrm{O}$ (4.97 wt.\%) with a high $\mathrm{K}_{2} \mathrm{O} / \mathrm{Na}_{2} \mathrm{O}$ weight ratio (2.2). The granite is weakly peraluminous $(\mathrm{A} / \mathrm{CNK}=1.6)$ with low $\mathrm{TiO}_{2}$ and $\mathrm{P}_{2} \mathrm{O}_{5}$. High $\mathrm{Rb}$ $(590 \mathrm{ppm}$ ) results in low $\mathrm{K} / \mathrm{Rb}$ ratio (70). The variation in $\mathrm{Rb}, \mathrm{Ba}$, and Sr (Fig. 4) corresponds to that of anomalous granites (El Bouseily and El Sokkary, 1975). Rb/Ba (4.2), and Rb/Sr (34.7) ratios are similar to aplitic Hercynian granites (Neiva, 1984), which are slightly anomalous compared to associated biotite granites in Spain. (Sample 6-1300 represents a portion of a pegmatite pod and hence has not been included in the discussion.)

All the granite samples contain normative corundum (0.5$3.3 \%$ ) (Table 1). Normative anorthite content ranges from 2.3 to 3.5 and in Figure 5, all analyses trend towards the thermal minimum $\left(730^{\circ} \mathrm{C}\right)$ for $\mathrm{H}_{2} \mathrm{O}$-saturated granitic liquid (3 wt.\% normative anorthite) at the $100 \mathrm{MPa}(1 \mathrm{~kb})$ eutectic of James and Hamilton (1969), indicating similar conditions for crystallization in the True Hill granite cupolas. The petrography and composition of the granite and greisen at True Hill suggest that fluorine was an additional volatile component (Table 1). Manning (1981) indicated a shift in the thermal minimum from $\mathrm{Q}_{37} \mathrm{Or}_{29} \mathrm{Ab}_{34}$ at $730^{\circ} \mathrm{C}$ and $\mathrm{F}=0 \%$ to $\mathrm{Q}_{15} \mathrm{Or}_{27} \mathrm{Ab}_{58}$ at $630^{\circ} \mathrm{C}$ and $\mathrm{F}$ $=4 \mathrm{wt} . \%$. Comparison of True Hill norms with Manning's results suggests a $F$ content less than 1 wt.\%.

Harker variation diagrams (Fig. 4) indicate that the True Hill granite is relatively homogeneous and similar in major- and trace-element composition to the Beech Hill series of granites. $\mathrm{K}_{2} \mathrm{O}$ correlates positively with $\mathrm{SiO}_{2}$ (Fig. 4). This substantiates the high $\mathrm{K}_{2} \mathrm{O} / \mathrm{Na}_{2} \mathrm{O}, \mathrm{Rb} / \mathrm{K}, \mathrm{Rb} / \mathrm{Sr}, \mathrm{SiO}_{2}, \mathrm{Al}_{2} \mathrm{O}_{3}$ and low $\mathrm{TiO}_{2}$ and $\mathrm{Zr}$ considered to be characteristic of the Beech Hill granite series (Ruitenberg and Fyffe, 1982). The Nova Scotian tin-specialized granite of Chatterjee et al. (1983) is very similar in composition to the True Hill granite.

The abundances of REE in selected True Hill granite samples show patterns characterized by high total REE, little fractionation of LREE relative to HREE $\left(\mathrm{La} / \mathrm{Lu}_{\mathrm{N}}=1.15\right)(\mathrm{Lent}, 1986)$, and a marked negative Eu anomaly (Fig. 6). Similar REE patterns have been found for topaz granites of Pleasant Ridge (Fig. 6) and Mount Pleasant (Taylor et al., 1985) and also confirm the REE analyses of Dagger (1972).

The REE distribution is typical of high-silica granites, reflecting their highly evolved nature and high fluorine content (Cullers and Graf, 1984; Taylor et al., 1985). The higher fluoride-ion concentrations in the vapour phase would increase the mobilization of the HREE from the magma similar to the effect for chlorine (Flynn and Burnham, 1978). The large negative Eu anomaly probably reflects retention of Eu by Kfeldspar and plagioclase, either as residual phases in the protolith or as early crystallizing phenocrysts fractionated from the melt (Cullers and Graf, 1984). Both these mechanisms are compatible with the strong depletion of $\mathrm{CaO}, \mathrm{Ba}$ and $\mathrm{Sr}$ in the True Hill granite.

The True Hill granite has characteristics of A-type granites (Taylor et al., 1985; Collins et al., 1982) with high $\mathrm{K}_{2} \mathrm{O}, \mathrm{Na}_{2} \mathrm{O}$,
$\mathrm{F}, \mathrm{Nb}, \mathrm{Y}, \mathrm{Zr}$ and REE. This is substantiated by the $\mathrm{Rb}, \mathrm{Nb}$, and Y empirical discrimination plots of Pearce et al. (1984) where True Hill falls in the within-plate field similar to the Eastern Saint George batholith (McLeod et al., 1988).

The "fresh" True Hill granite contains $6.8 \mathrm{ppm} \mathrm{Sn,} 1.5 \mathrm{ppm}$ $\mathrm{Bi}$ and $5 \mathrm{ppm}$ Mo (Lentz, 1986) which is much lower in tin but slightly higher in molybdenum compared to the tin-granite of Chatterjee et al. (1983). A non-uniform distribution of sphene and biotite probably accounts, in part, for variation in tin values ranging from 10 to $100 \mathrm{ppm}$ obtained from $321.5 \mathrm{~m}$ of weakly altered to unaltered granite core (Lutes, unpublished data).

\section{Alteration}

Alteration and mineralization at True Hill straddles the contact between the granite and the host rock similar to thc situation in the model system of Shcherba (1970) (Fig. 8a). Detailed investigation of greisen zones including thin section and SEM study and whole rock chemical analysis were done on DDH\#80-3 and DDH\#80-6 from cupola B and C, respectively (Figs. 2,3), representing a section through the altered granitc carapace into unaltered granite.

Greisen selvages have formed around joints and fractures in cupolas B and C and within metasedimentary host rocks. Pervasive greisen alteration is focussed along the contacts between the granite and the homfelsed metasedimentary rocks. In a few areas, the contact is obscured by intense alteration or quartz veining. These crude veins are very similar to the deeper portions of the W-Mo-Bi ore zone at Mount Pleasant as described by Pouliot et al. (1978), Parrish and Tully (1978) and Dagger (1972). Cupola A, like that at Beech Hill, represents a slightly deeper portion of the granite, with very little vein-type greisen developed.

Three types of endogreisen, probably reflecting variations in the hydrothermal fluid, are developed at True Hill:

(1) Fluorite-bearing, quartz-sericite greisen;

(2) Fluorite-bearing, quartz-chlorite-sericite greisen;

(3) Fluorite-bearing, quartz-topaz-sericite greisen.

The first and third types of greisen host most of the visiblc bismuthinite, molybdenite and wolframite mineralization whereas the chlorite-bearing assemblage visibly hosts the sphalerite, chalcopyrite and galena mineralization, as well as having anomalous tin contents.

The chemical composition of the metasedimentary rocks and xenoliths imposes chemical controls on the mineral ass $\mathrm{cm}$ blages developed in the exogreisen environment. Lund (1981) and Lentz (1986) have documented abundant mica alteration in the proximal contact zone of the cupola with locally abundant brecciation and silicification. More distally, $(10-100 \mathrm{~m})$ chlorite, mica and tourmaline alteration are dominant, especially within cupola C.

Multiple greisen vein systems commonly overprint each other and thus indicate several episodes of volatile exhalation from the crystallizing magma. In some places, the changing nature (acidity and salinity) of the greisenizing fluids in the upper portions of the granite resulted in rhythmically-banded, quartztopaz-sericite greisen. This greisen is identical to those observed 

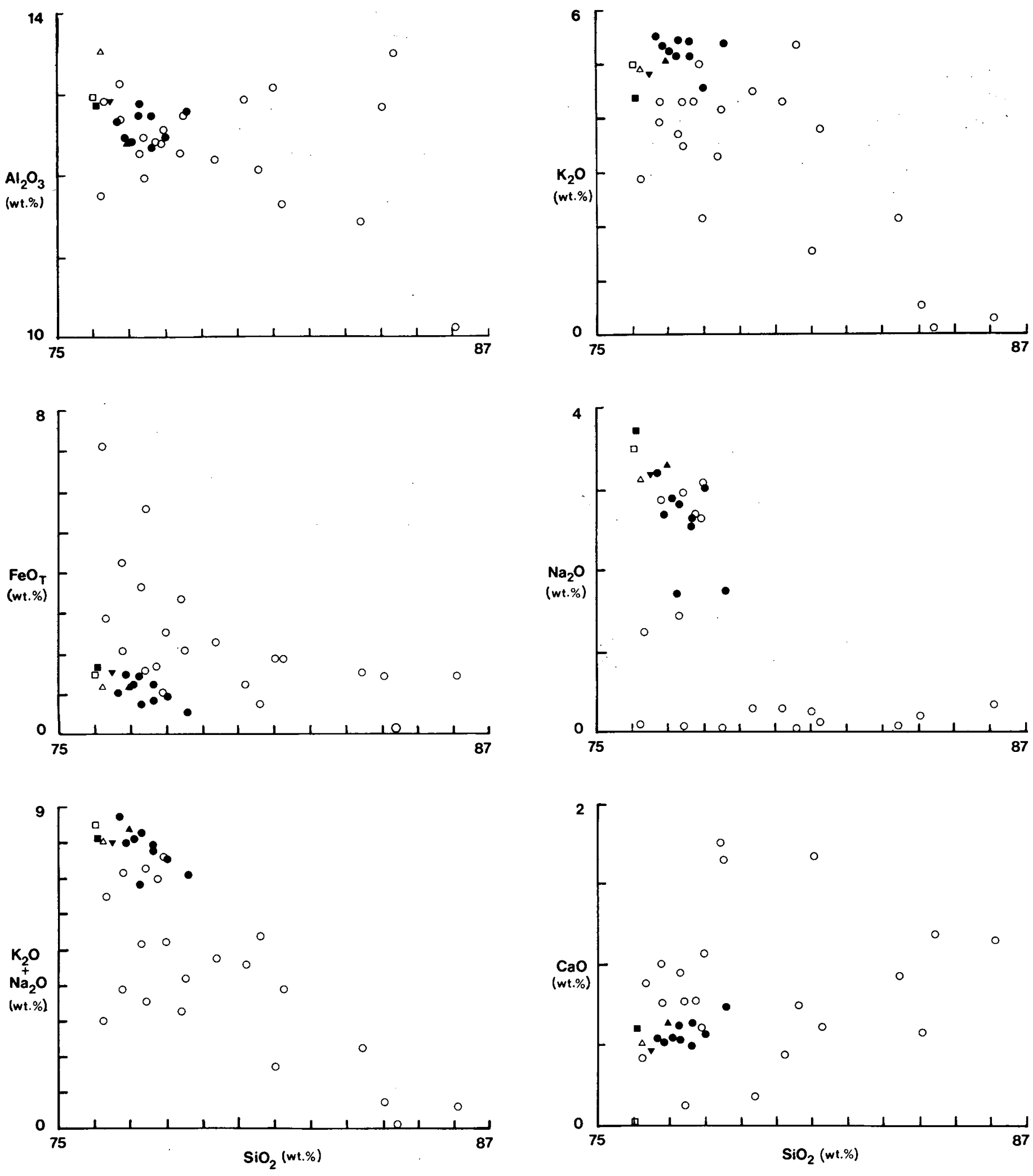

Fig. 4. Silica variation diagrams for $\mathrm{Al}_{2} \mathrm{O}_{3}, \mathrm{FeO}_{\mathrm{T}}, \mathrm{K} 2 \mathrm{O}+\mathrm{Na}_{2} \mathrm{O}, \mathrm{K}_{2} \mathrm{O}, \mathrm{Na}_{2} \mathrm{O}, \mathrm{CaO}, \mathrm{Rb}, \mathrm{Sr}, \mathrm{Ba}, \mathrm{Rb} / \mathrm{Sr}, \mathrm{Y}, \mathrm{Nb}, \mathrm{K} / \mathrm{Rb}, \mathrm{Al}_{2} \mathrm{O} / \mathrm{K}_{2} \mathrm{O}+\mathrm{Na}_{2} \mathrm{O}, \mathrm{CaO}$ vs $\mathrm{F}, \mathrm{Rb}$ vs $\mathrm{F}$, and $\mathrm{Nb}-\mathrm{Zr}$-Y and Rb-Ba-Sr ternary plots. (Open circles are greisen samples; the remaining samples are granites (see Fig. 5 for symbols)). 

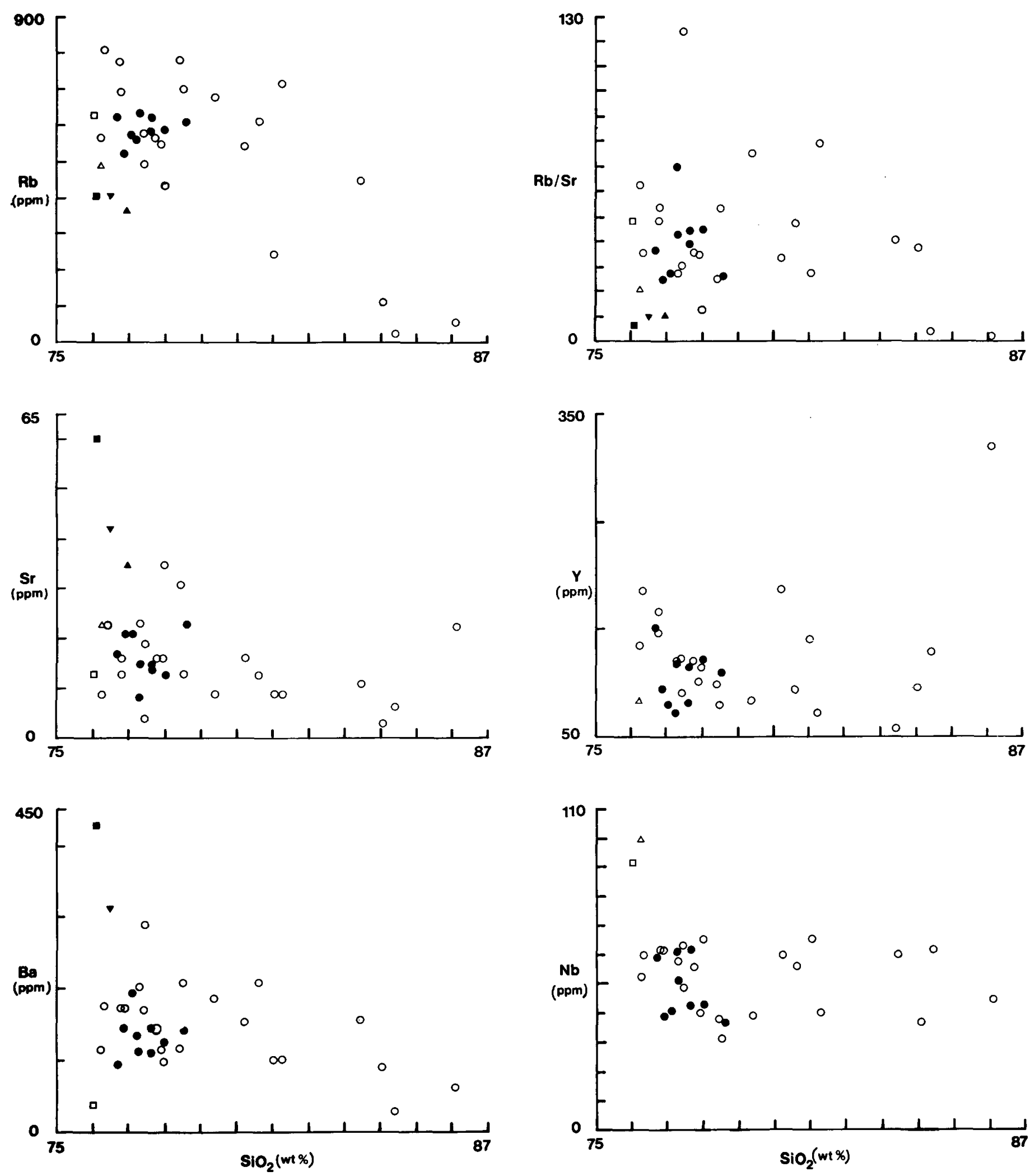

Fig. 4 Cont. 

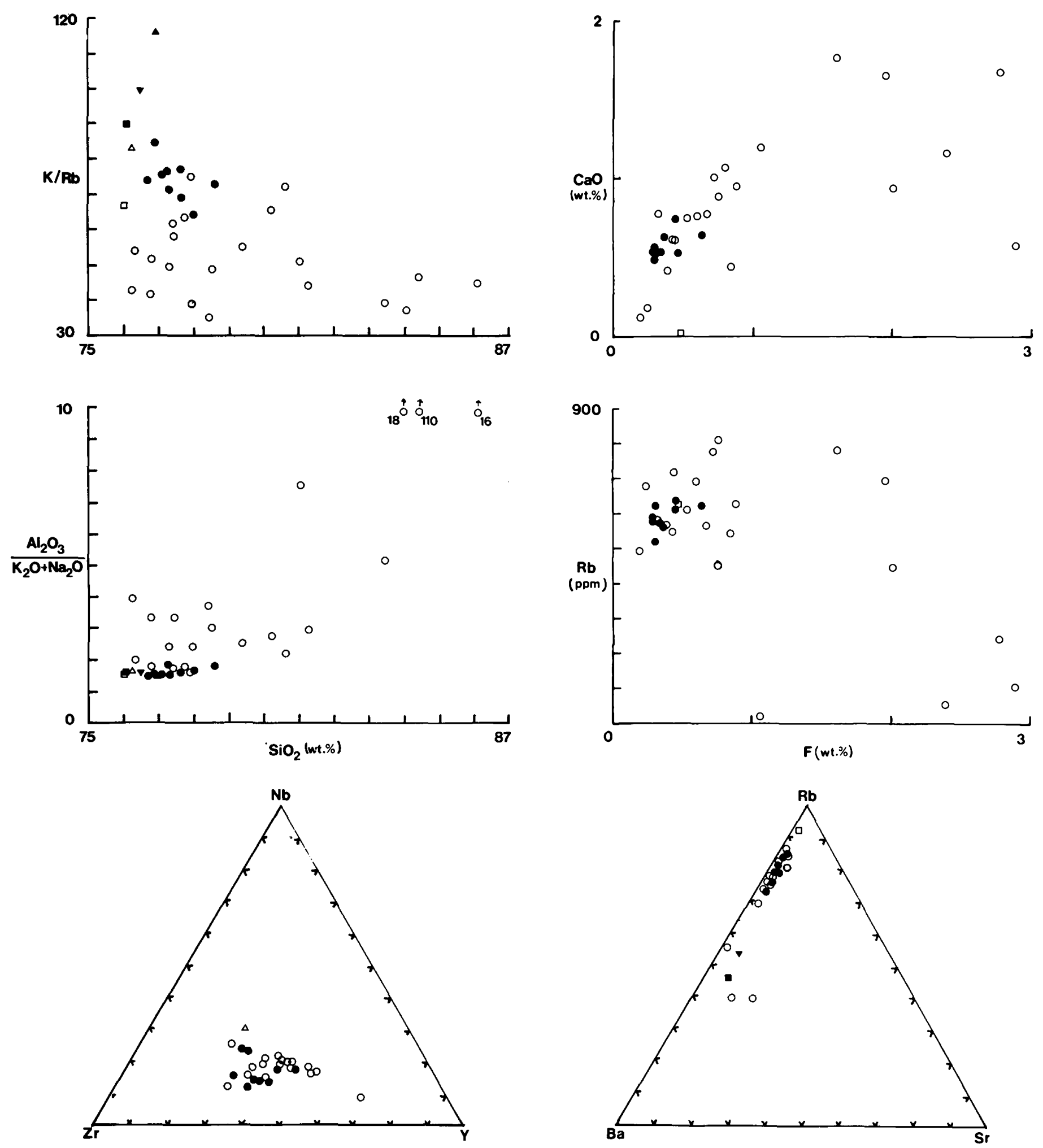

Fig. 4 Cont. 


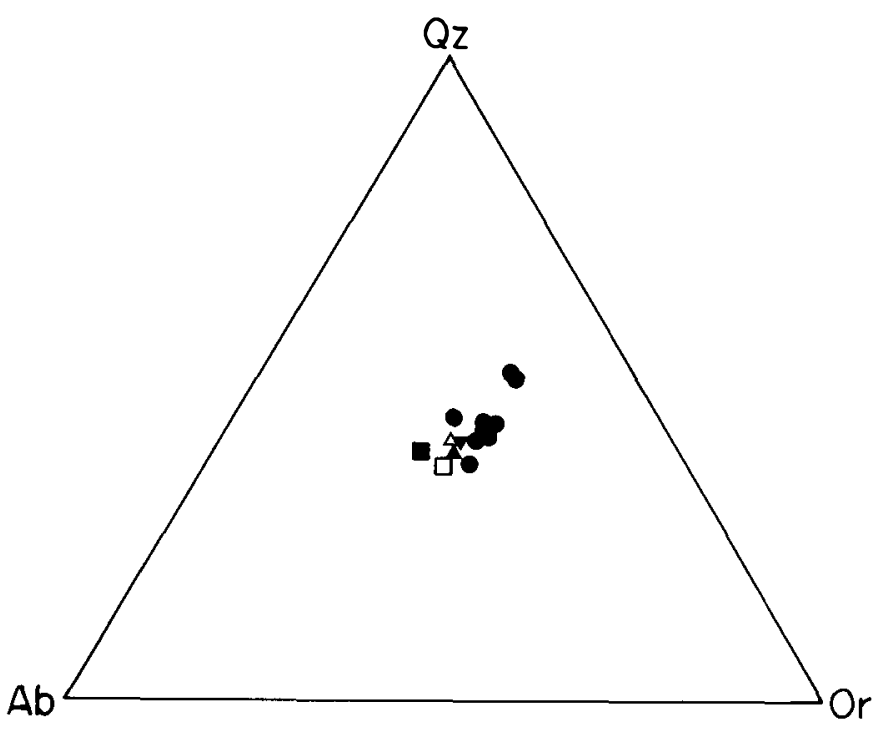

Fig. 5. Quartz (Qtz) - Albite (Ab) - Orthoclase (Or) ternary diagram. C.I.P.W. normative mineralogy for fresh True Hill granite porphyry and associated granite plutons.

-True Hill granite (this study)

$\triangle$ True Hill average granite $(n=3)$ (Dagger, 1972)

$\square$ Beech Hill average granite $(n=16)$ (Butt, 1976)

$\Delta$ Eastern Saint George average granite $(n=17)($ Cherry, 1976)

DMount Pleasant fine-grained granite (Kooiman et al., 1986)

$\nabla$ Sórel Ridge average granite $(n=3)$ (Buth, 1976)

in surface exposures above the Mount Pleasant W-Mo-Bi orebody and at the Climax Mo deposit (White et al., 1981).

Albite alteration is weakly developed in apical portions of the True Hill granite porphyry, but is preserved locally in the deeper portions. Some of this secondary albite $\left(\mathrm{An}_{3}\right)$ contains abundant inclusions of secondary mica and represents albitization of pre-existing mineral phases. Secondary albite most commonly replaced K-feldspar. Alteration of primary plagioclase is also common at True Hill, suggesting a model for the derivation of sodium from incongruent dissolution of plagioclase. Calcium released from this process may have contributed to the fluorite commonly found in areas of alteration.

$\mathrm{K}$-feldspathization and biotitization associated with quartz veining in the exogranitic environment suggest potassium metasomatism associated with deuteric alteration. Dagger (1972) observed a similar phenomenon associated with feldspathized (orthoclase) portions of the fine-grained granite beneath the $\mathrm{W}$ Mo-Bi orebody at Mount Pleasant, as substantiated by the observations of Kooiman et al. (1986) and Pouliot et al. (1978).

Topaz alteration is usually associated with the quartz-topazsericite greisen that is more abundant in cupola C. Topaz and quartz commonly form the center of the vein with selvages of secondary sericite and both secondary and residual quartz. Muscovite and topaz were produced by hydrogen metasomatism which was responsible for hydrolysis reactions that released alkali elements and silica. First and second boiling of deuteric hydrothermal fluid seems to have been responsible for the high acidities associated with the mica and topaz-mica alteration, as has been proposed by Davis and Williams-Jones (1985) for the W-Mo-Bi mineralized zones at Mount Pleasant.

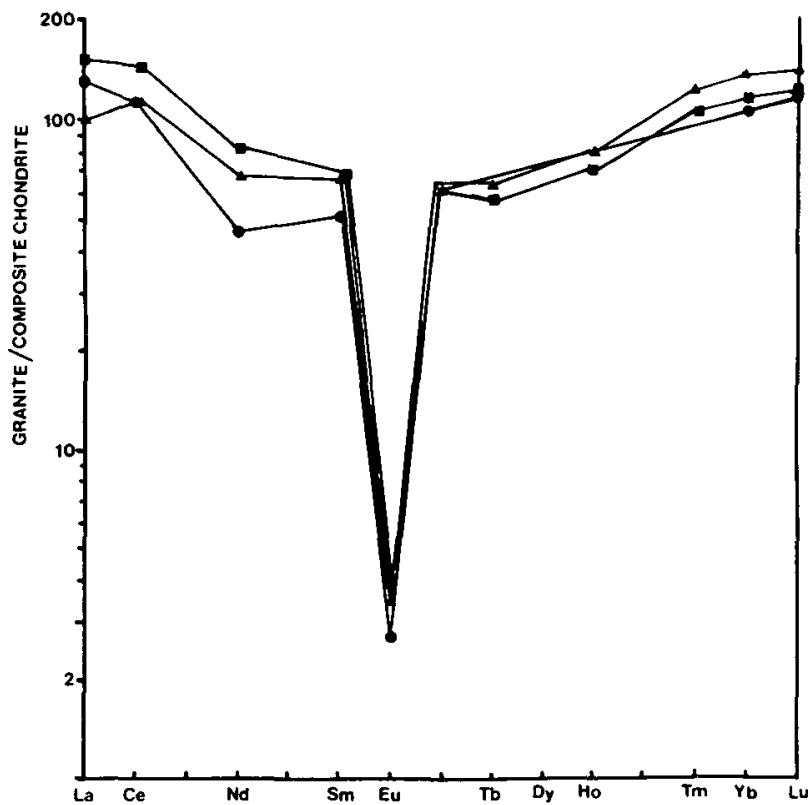

Fig. 6. Chondrite-normalized rare-earth-element pattems for True Hill granite (square) (Lentz, 1986) and Pleasant Ridge granite (circle) and for porphyritic Mount Pleasant granite (Taylor et al., 1985).

Silicic alteration is associated with all types of greisenization. Seriated quartz grain boundries (dissolution of quartz) and replacement of feldspar by mica and topaz (incongruent dissolution of feldspars) during hydrolysis reactions are responsible for the increased solution of silica. Pervasive silica alteration is most closely associated with cupola $\mathrm{C}$ along the margins of the exposed cusp. Quartz veins and quartz-centered greisen veins are common in both the endogranitic and exogranitic environments. The present distribution of the most siliceous alteration (vein cores, fractures, and in the cupola) seems to favour a decrease in silica solubility due to a decrease in the geostatic pressure during hydrofracturing and vein formation.

Sericitization is the most common type of alteration associated with greisen veins in cupolas $B$ and $C$. Hydrolysis reactions involving primary igneous minerals and alkali metasomatism are the main factors responsible for the formation of sericite in all stages of greisenization based on petrographic observations.

Similar to sericitization, chlorite alteration may form during the destruction of biotite or due to the introduction of $\mathrm{Fe}, \mathrm{Mg}$ and Mn during alteration of feldspar. The progressive destruction of biotites in granites has been used to explain the enrichment $\mathrm{Fe}$, $\mathrm{Mn}$ and $\mathrm{Sn}$ in post-magmatic fluids (Taylor, 1979). Fe, Mg and Mn metasomatism at True Hill, manifested mainly as chlorite alteration, occurs both in veins and locally as pervasive zones. Chlorite-bearing assemblages are slightly more enriched in tin relative to other types of alteration indicating that tin enrichment is associated with the alteration of tin-bearing ferromagnesium minerals (Lentz, 1986). Pyrite and magnetite are present in variable proportions in the quartz-chlorite-sericite greisen zones.

Tourmaline alteration is restricted mainly to the metasedimentary rocks and is associated with all types of alteration developed in the exogranitic environment. In one instance, greisenizing solutions interacted with a large metasedimentary 
xenolith in cupola $\mathrm{C}$ to produce both chlorite and tourmaline alteration in the xenolith and the granite above the xenolith. Coarse schorl is developed in areas of silicified metasedimentary rocks and fine-grained varieties are common in metasedimenthosted greisen veins. Tourmaline alteration has not been documented in the deposits of Mount Pleasant or the Saint George batholith, although tourmaline has been identified from vein systems developed in metasedimentary rocks, suggesting a metasedimentary derivation for the boron.

Fluorite is associated with all types of alteration, but has not conclusively been identified as a primary magmatic phase. Fixation of fluorine as fluorite is most likely due to an increase in the activity of $\mathrm{Ca}$ in the HF-bearing hydrothermal fluid related to the alteration of plagioclase. This inter-pretation is favoured by the abundant fluorite associated with proximal exogranite alteration.

\section{CHEMICAL COMPOSITION OF ALTERED ROCKS}

The greisen-type alteration at True Hill is similar to that found at Mount Pleasant below the subeconomic W-Mo-Bi orebody. At True Hill, analyses of quartz-sericite greisen by Billiton Canada Ltd. indicate an average of $10-20 \mathrm{ppm} \mathrm{W}$ that locally increases to $>100 \mathrm{ppm} \mathrm{W}$ as visible wolframite. Molybdenum averages $5 \mathrm{ppm}$ with quartz veins commonly reaching $>100 \mathrm{ppm}$ Mo. In the quartz-chlorite-sericite greisen, tin content is commonly less than $30 \mathrm{ppm}$ although, rarely, values up to 300 ppm are found. Bismuth is present in very high concentration occurring as bismuthinite. Analysis of 183 mineralized zones (courtesy of Billiton Canada Ltd.) indicate an average of $295 \mathrm{ppm}$ Bi. Sphalerite (50-10000 ppm Zn), galena (20-10000 ppm Pb) and chalcopyrite (5->500 ppm $\mathrm{Cu})$ are commonly associated with the chlorite-bearing greisen. Silver analyses indicate an average of $0.1 \mathrm{ppm} \mathrm{Ag}$, but as much as $2.1 \mathrm{ppm} \mathrm{Ag}$ are associated with the sulfide mineralized zones. Fluorine analyses (by Beth Canada Ltd. from Billiton Canada Ltd.) of numerous greisenized granite and metasedimentary rock samples range from 0.3 to greater than $2 \mathrm{wt} . \%$, coincident with visible fluorite in the assemblage. There are poor, if any, correlations between the elements $\mathrm{Bi}, \mathrm{Mo}, \mathrm{Sn}$, and $\mathrm{W}$ based on assay values of core from DDH\#80-3 and DDH\#80-6 but a much stronger relationship between $\mathrm{Sn}, \mathrm{Cu}, \mathrm{Zn}$, and $\mathrm{Pb}$ (Fig. 7). This seems to support the observation that cassiterite and sulfide mineralization is associated with the quartz-chlorite-sericite greisen assemblage.

Chemical analyses of weak to moderately greisenized samples from True Hill (Table 2) compared with analyses of unaltered granite (Fig. 4) show that variations in $\mathrm{Fe}_{2} \mathrm{O}_{3}, \mathrm{MnO}$ and $\mathrm{MgO}$ abundances are related to the variably developed chlorite-bearing mica alteration. $\mathrm{Na}_{2} \mathrm{O}$ and to a lesser extent $\mathrm{K}_{2} \mathrm{O}$ depletion reflects the mobilization of alkali elements during feldspar alteration to chlorite and sericite assemblages. The removal of $\mathrm{K}_{2} \mathrm{O}, \mathrm{Na}_{2} \mathrm{O}$ and $\mathrm{CaO}$ results in an increase in the relative proportions of $\mathrm{Al}_{2} \mathrm{O}_{3}$ and $\mathrm{SiO}_{2}$. High normative corundum values are associated with the relative enrichment in $\mathrm{Al}_{2} \mathrm{O}_{3}$ and a decrease in the $\mathrm{Na}_{2} \mathrm{O} / \mathrm{K}_{2} \mathrm{O}$ ratio compared to unaltered granite. High calcium content of greisen is coincident with the presence of fluorite.
The abundances of trace elements in the greisenized granite reflect their relative mobilities during hydrothermal alteration. $\mathrm{Zr}, \mathrm{Y}$ and $\mathrm{Ti}$ are relatively immobile during greisenization and thus have abundances similar to those in the unaltered granite (Fig. 4). In contrast, $\mathrm{Rb}, \mathrm{Sr}, \mathrm{Ba}$ and $\mathrm{Nb}$ have been locally redistributed, and in general $\mathrm{Rb} / \mathrm{Ba}$ and $\mathrm{Rb} / \mathrm{Sr}$ ratios increase during greisenization (cf.Neiva, 1984), although this contradicts the findings of Ekwere (1985). Detailed analyses of the chemistry of the exogranite mineralized zones has not been attempted, mainly because of the variable mineralogy of the intercalated graywacke and shale sequence in the True Hill area. Petrographic features of exogranite mineralized zones are complex and are strongly controlled by host rock composition (Lentz, 1986).

\section{COMPARISON OF THE TRUE HILL, SAINT GEORGE BATHOLITH, AND MOUNT PLEASANT MINERALIZED ZONES}

The cupola greisen alteration and mineralization at True Hill is similar to W-Mo-Bi mineralized zones developed above the fine-grained granite at Mount Pleasant and within the Eastern Saint George batholith as documented below.

Three textural varieties have been identified within the Victoria Lake area and Square Lake area of the Eastem Saint George batholith. Intrusive relationships indicate that these are from oldest to youngest: (1) coarse-grained seriate biotite granite, (2) medium- to fine-grained porphyritic biotite granite, and (3) medium-grained equigranular biotite granite (McCutcheon and Ruitenberg, 1983; MacLellan, 1983). The coarse-grained, seriate biotite granite represents the marginal portion of the Eastem Saint George granite batholith. Cherry (1976) has analysed the two earliest units of the intrusion, both petrographically and chemically. These units differ texturally and in the redox state of the iron. The medium to fine-grained granite locally contains pegmatite pods and granophyre similar to the True Hill granite and the fine-grained Mount Pleasant granite.

McLeod et al. (1988) and MacLellan (1983) have described three types of greisen mineralization, including quartz-sericite, quartz-chlorite-sericite, and quartz-topaz-sericite types. All may occur within small areas with complex crosscutting relationships and are most abundant near contacts between the coarse-grained granite and the finer-grained types of granite. Accessories include fluorite, pyrite, chalcopyrite, arsenopyrite, magnetite and hematite. Wolframite and molybdenite are the most conspicuous ore minerals but are erratically distributed. Marginal pegmatites ('stockschieder') are locallized along the contacts between the intrusive phases and at the base of sedimentary enclaves. The greater abundance of pegmatite associated with the fine-grained porphyritic biotite granite seems to indicate that they formed at a slightly higher pressure than the True Hill granite, as proposed in the depth classification of Varlamoff (1978).

The spatial distribution between alteration and mineralization at True Hill, Mount Pleasant, and in the Saint George granite are schematically represented in three cross-sections (Fig. 8a, b, $c$ respectively). The distribution of alteration in each instance is focused predominantly into local cusps in the irregular roof of 

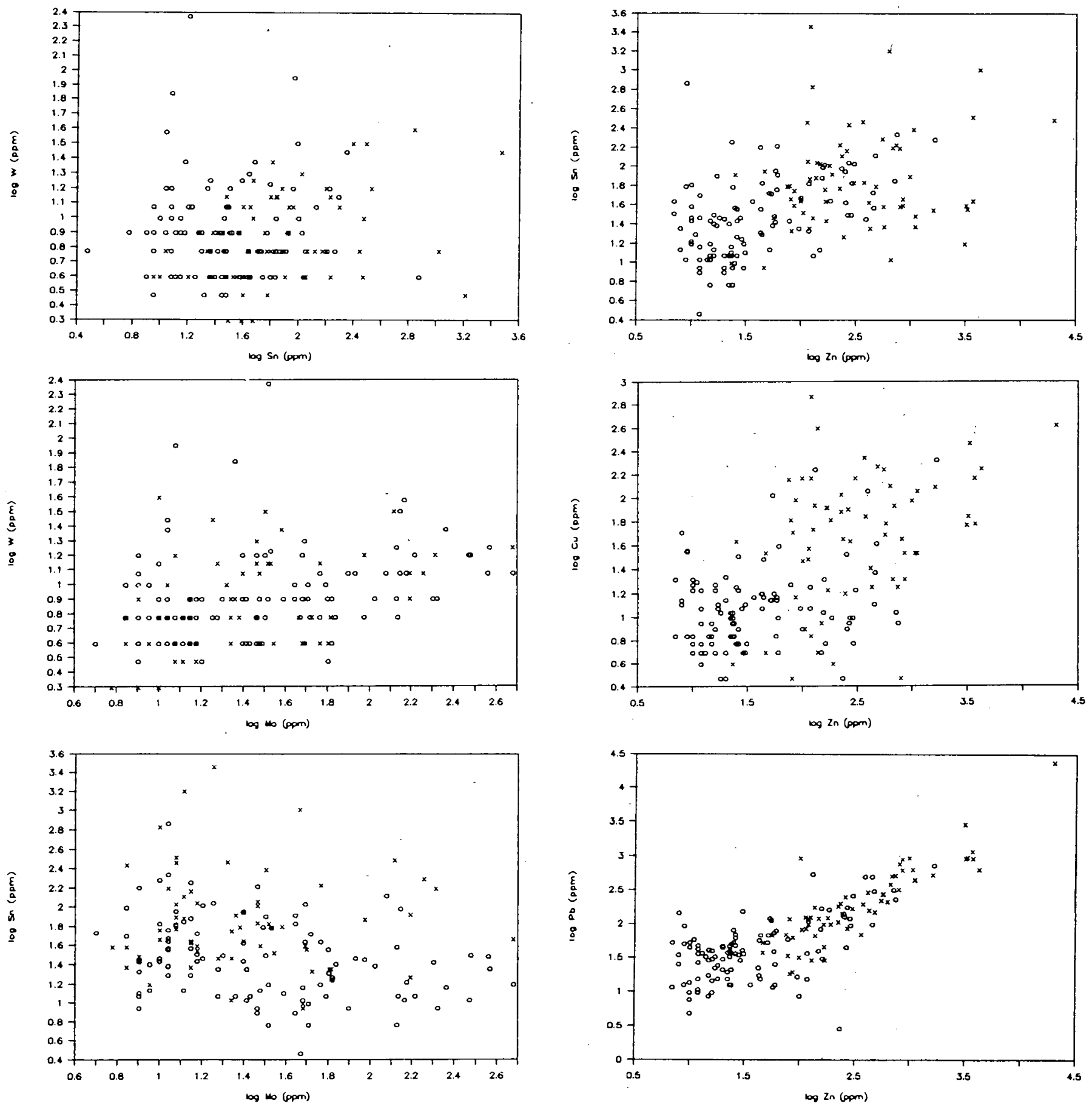

Fig. 7. Log plots of chemical analyses of drill core from DDH\#80-3 (o) and DDH\#80-6 (x). Data are from assessment reports.

these granites. In each case the granites have undergone vapour phase separation (resurgent boiling or second boiling) resulting in the quenching of a heterogeneously crystallizing magma. The deuteric fluids involved in the mineralization process have produced variable degrees of alteration and host rock preparation for the migration of fluids (e.g., see Burnham and Ohmoto, 1980).

The presence of marginal pegmatites developed along the contact between the coarse-grained seriate granite and porphyritic granite of the Eastern Saint George batholith seems to indicate that these granites crystallized under slightly higher lithostatic pressure (upper mesoabyssal?) or exsolved smaller amounts of fluids than the True Hill (upper mesoabyssal to hypabyssal?) or Mount Pleasant (subvolcanic) granites. In either case the competency of the coarse-grained granite was enough to retain many of the hydrothermal fluids in the cusp of the intrusion during crystallization of the pegmatite. The absence of marginal pegmatites and the greater intensity of hydrofracturing and brecciation at True Hill and Mount Pleasant indicate a slightly shallower level of emplacement, higher volatile content or less competent host rock (Burnham and Ohmoto, 1980). 
Table 2. Whole rock chemical analyses* of granite samples from True Hill displaying weak, moderate and intensc greisenization (see Lentz (1986) for description).

\begin{tabular}{|c|c|c|c|c|c|c|c|c|c|c|c|c|c|c|c|c|c|c|c|c|c|}
\hline ;ample & 314 & $\begin{array}{c}3-332 \\
==-==-=\end{array}$ & $\begin{array}{c}3-350 \\
==-==\end{array}$ & 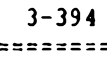 & $\begin{aligned} & 3-526 \\
==-= & ==\end{aligned}$ & $\begin{aligned} & 3-537 \\
=== & ==-\end{aligned}$ & $\begin{array}{c}3-573 \\
====-=\end{array}$ & $\begin{array}{l}6-45 \\
==-==\end{array}$ & $\begin{aligned} & 6-100 \\
= & ==-=\end{aligned}$ & $\begin{array}{c}6-164 \\
:===-=\end{array}$ & $\begin{array}{c}6-181 \\
====-=\end{array}$ & $\begin{array}{c}6-336 \\
:==-==-\end{array}$ & $\begin{array}{c}6-371 \\
==-==2=\end{array}$ & $\begin{aligned} & 6-415 \\
= & =-=\end{aligned}$ & $\begin{aligned} & 6-471 \\
== & ====\end{aligned}$ & $\begin{aligned} & 6-480 \\
== & ==-=\end{aligned}$ & $\begin{aligned} & 6-518 \\
= & ==-=\end{aligned}$ & $\begin{aligned} & 6-667 \\
== & ==-=\end{aligned}$ & $\begin{aligned} & 6-728 \\
&:==-1\end{aligned}$ & $\begin{array}{r}6-739 \\
===-==\end{array}$ & $\begin{array}{r}6-937 \\
===-===\end{array}$ \\
\hline 02 (wt. s) & 77.85 & 77.06 & 75.86 & 82.26 & 78.09 & 76.27 & 76.36 & 78.51 & 75.18 & 77.97 & 75.14 & 78.48 & 81.74 & 77.08 & 76.53 & 75.12 & 76.03 & 86.72 & 81.69 & 76.76 & 79.71 \\
\hline & & & & & & & & & & 0. & & & & & 0.05 & & & & & & \\
\hline & 11. & 12 & 11.7 & 13 & 12. & 12.12 & 12. & 6 & 11 & 12 & 12 & 12.66 & 11.21 & 12.52 & 12.24 & 12.70 & 12.57 & 10.20 & 12.48 & 12.01 & 11.43 \\
\hline & & & & & 2 & 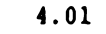 & 15 & & 9 & 2. & 1.61 & & & 2.28 & 1.81 & 3.12 & 2.28 & 1.60 & & 3.64 & 2.02 \\
\hline & 0 & 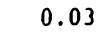 & & & & & 0 . & 0 . & 0 . & 0 . & 0. & & 0.03 & 0.16 & 0. & 0.05 & 0.05 & 0.06 & 0.06 & 0.07 & 0.16 \\
\hline & 0. & 0 . & & & 0 & 0. & 0 & v. & 0 . & 0. & 0 . & & & 0. & 0 . & 0.10 & & 0 . & & & 0.27 \\
\hline & & 0 . & & 1 & 0 & 0 & 0. & 0 . & 0 . & 1. & 0 . & & 0.92 & 1. & 0 . & 0.87 & 0.76 & & & 1.73 & 0.60 \\
\hline & & 2. & & 0 . & 0 . & & & 0 & 0 . & 0. & 0 . & & & 0. & 2. & 1.21 & 2.83 & 0.35 & & & 0.11 \\
\hline & & 4. & & & 4. & & 4. & & 2. & 1. & & & & 4. & 4. & 5.18 & 4.27 & & 0.49 & 3.23 & 3.71 \\
\hline & & 0. & & & & & & & 0 . & 0. & & & 0. & 0 . & 0. & 0.01 & 0.01 & 0. & & & 0.01 \\
\hline & & 0.91 & & 2. & 2. & & & & 0. & 2.24 & 2. & & & & & 1.46 & 1. & & 9 & 2.42 & 2.25 \\
\hline 00 & 99. & 100.46 & 100.14 & 100.24 & 99. & 100.4 & 98. & 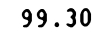 & 98.76 & 98.46 & 100.50 & 102.52 & 99.95 & 99.66 & 99.62 & 99.88 & 100.07 & 103.86 & 98 & 100.31 & 100.36 \\
\hline & & & & & & & & & & & & & & 1. & 0. & 0.7 & 0. & & & 1.61 & \\
\hline ( w & & & & & & & & & & & & & & & & & & & & & 0.21 \\
\hline 1 & 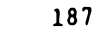 & & & & & & & & & & & 97 & & & 14 & 74 & & 60 & 88 & 18 & 100 \\
\hline & 0 & 0 & 2 & & & & 1 & & & $\varepsilon$ & & 8 & & & 0 & 2 & & & 26 & 4 & $\begin{array}{r}15 \\
105\end{array}$ \\
\hline $\mathrm{Z}$ & 127 & 12 & & & & & & & & & 1 & 1 & & 15 & & & & & 14 & 118 & 105 \\
\hline & & 1 & & & & & 1 & & & 9 & & & 1 & 1 & 1 & & & & 3 & 31 & \\
\hline & & & & & & & & & & & & & 4 & 70 & & & 6 & 53 & 113 & 782 & 18 \\
\hline & 8 & & 9 & & & & & & & & & & 5 & 7 & & & & 32 & 96 & 99 & 73 \\
\hline & 3 & & 4 & & & & & & & & & & & & & & & 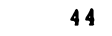 & 37 & 38 & 40 \\
\hline & & & 4 & & & & & & & & & & & 8 & 5 & 11 & & 61 & 46 & 75 & 91 \\
\hline $\mathrm{Ni}$ & 40 & & & & & & 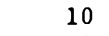 & 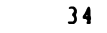 & 2 & 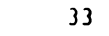 & 3 & 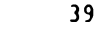 & 22 & S3 & 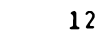 & 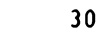 & & 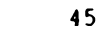 & 17 & 20 & 32 \\
\hline V & 0 & . & 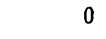 & 0 & & 0 & 0 & 0 & 0 & 0 & n & 0 & 0 & 0 & 5 & 0 & 8 & 11 & 5 & 0 & \\
\hline & & & & & & & & & & & & & & & & & & & & 11 & 0.88 \\
\hline & & & & & & & & & & & & & & & & & & & & & \\
\hline & & 6. & & & & & & & & & & w & & & & & & & & & \\
\hline $\mathrm{K} / \mathrm{Ba}$ & 95.00 & 208.00 & 97.30 & .60 & 227.30 & 148.90 & 359.20 & 207.70 & 209.30 & 119.2 .0 & 185.90 & 184.00 & 111.20 & .60 & 242.10 & 247.10 & 206.10 & 40.10 & 46.20 & 227.20 & $30 \% .90$ \\
\hline
\end{tabular}

*Analytical methods as in Table 1.

Degree of alteration in analyzed samples varies as follows:

Hole 80-3; weak - 332, 526

weak to moderate - $394,537,573$

moderate - 314

moderate to intense - 350

Hole $80-6$; weak to moderate - 336, $518,739,937$

moderate - $45,471,480$

moderate to intense - 100

intense - 164, 181, 371, 415, 667, 728 

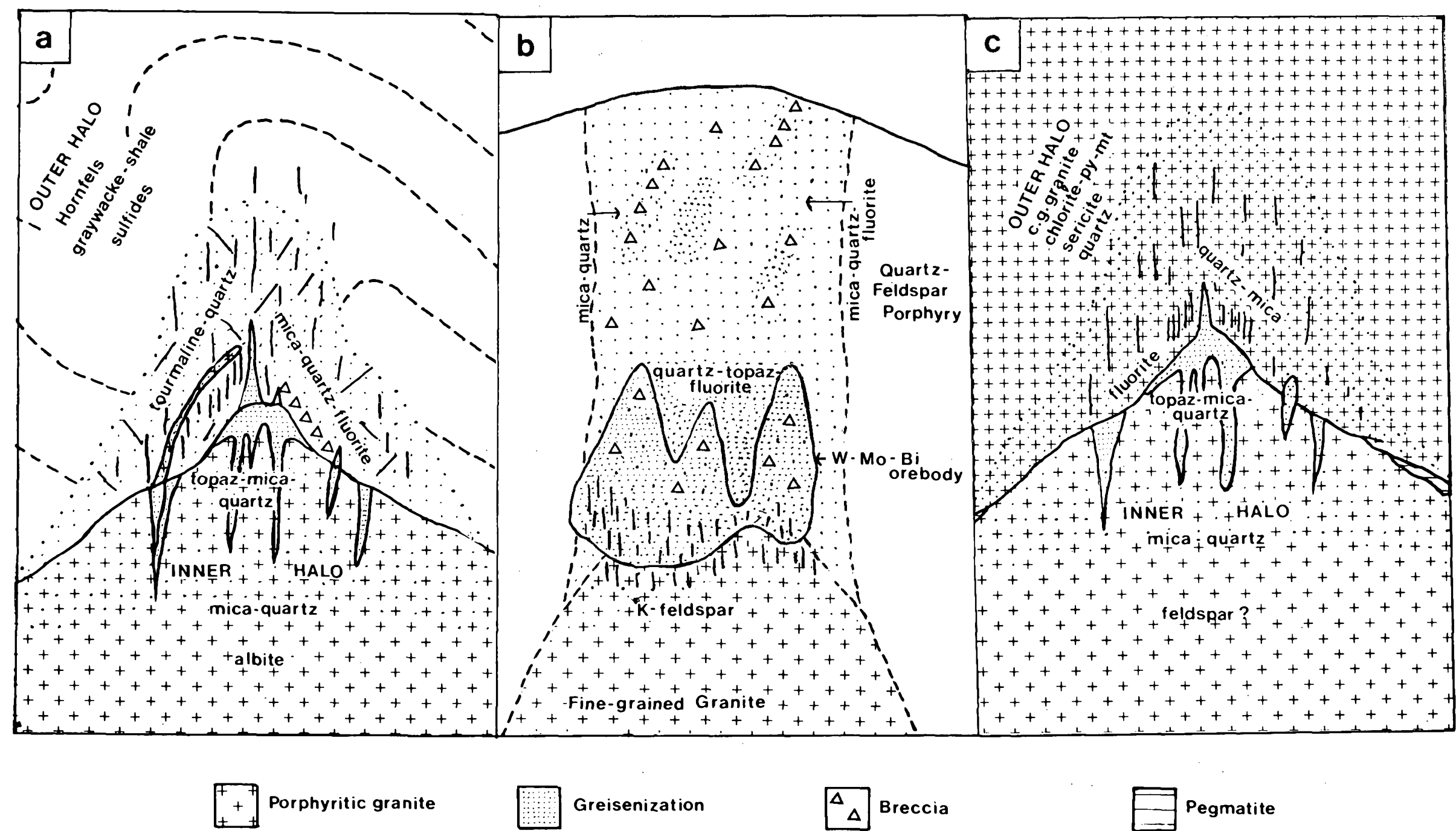

Greisenization

$\Delta \Delta$ Breccia

Pegmatite

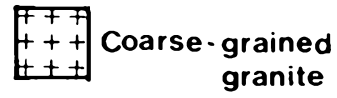

Greisen veins

Silurian metasediments

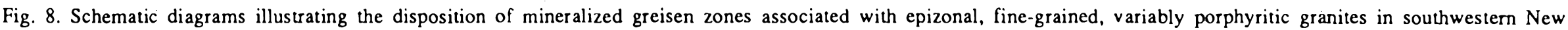

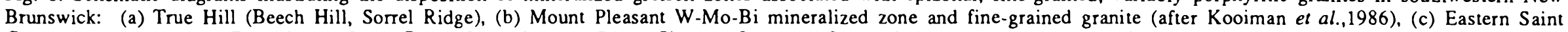

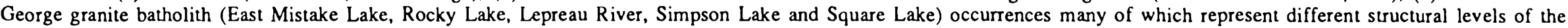

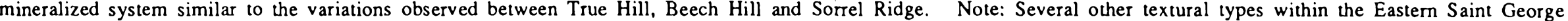
batholith associated with mineralization have not been included in this discussion. 
Davis and Williams-Jones (1985) found that the minerals at Mount Pleasant, within the quartz-topaz greisen which is associated with the W-Mo-Bi mineralized zones, contain four types of fluid inclusions. The data seems to favour second boiling of a low-volatile melt followed by first boiling of the supercritical fluid. This is compatible with the deposition of $\mathrm{W}, \mathrm{Mo}$ and $\mathrm{Bi}$ due to destabilization of their complexes as a result of first boiling (Drummond and Ohmoto, 1985), and abundant pervasive silicification due to a decrease in geostatic pressure (Holland and Malinin, 1979; Dagger, 1972; Parrish and Tully, 1978; Pouliot et al., 1978). The intense greisen alteration also indicates that first boiling may be responsible for the low $\mathrm{pH}$ fluids compatible with the quartz-topaz and quartz-sericite topaz alteration zones (Burt, 1981; Burnham and Ohmoto, 1980).

Pressure estimates for the depth of formation of the Mount Plcasant deposit are $450 \mathrm{~m}$ based on stratigraphic evidence (Parrish and Tully, 1978) and 13 to $47.5 \mathrm{MPa}$ based on type II (vapour-rich) fluid inclusions and salt dissolution measurements (Davis and Williams-Jones, 1985). The large pressure variations are compatible with large changes in geostatic pressure in this cnvironment (Bumham and Ohomoto, 1980). Similar mechanisms are also responsible for the distribution of mineralization and alteration at True Hill, similar to those at the Climax Mo deposit.

These three environments are most similar to the Erzgebirge style mineralization as described by Baumann (1970) and summarized by Taylor (1979). The variation in intensity of mineralization at True Hill versus Mount Pleasant is due to several factors which include abundance of volatiles, depth of intrusion, composition of volatile phase, efficiency of partitioning, incongruent and congruent dissolution of minerals hosting ore-forming elements during intergranular and vein infiltration of deuteric fluids, as well as the efficiency of the depositional mechanisms.

\section{CONCLUSIONS}

The True Hill granite forms three cupolas intruded into Silurian metasedimentary rocks. Endogreisen and exogreisen are well developed in two of the three cupolas. The granite contains phenocrysts of quartz, K-feldspar and lesser plagioclase and biotite with a mineralogically similar matrix. Accessory minerals occurring with biotite are sphene, zircon and opaque phases. Granophyric patches, miarolitic cavities and pegmatite pods indicate that the granite is epizonal and evolved a vapour phase. Major-and trace-element composi-tions establish that the True Hill granite is a highly evolved, corundum-normative, Atype granite, similar to the Mount Pleasant granite and portions of the Eastern Saint George batholith. Normative mineralogy indicates that crystallization of the True Hill granite occurred at approximately $100 \mathrm{MPa} \mathrm{P}\left(\mathrm{H}_{2} \mathrm{O}\right)$ and a temperature between $700^{\circ} \mathrm{C}$ and $730^{\circ} \mathrm{C}$.

The greisen developed in cupolas $\mathrm{B}$ and $\mathrm{C}$ is complicated by overprinting of various types of alteration reflecting multi-stage devolatilization of the magma. The most intense low-pH micatopaz alteration is confined mainly to the apical portions of the granite whereas albite alteration occurred in the deeper portions. Albitization, silicification, sericitization, chloritization, tour- malinization and fluoritization reflect the physical and chemical changes in the hydrothermal fluid derived principally by second boiling of the magma and first boiling of the volatile phase. Analyses of drill core by Billiton Canada Ltd. and Beth Canada Ltd., indicate that typical concentrations of ore elements are: 1060 ppm W, 5-100 ppm Mo, 30-300 ppm Sn, 5-10000 ppm Bi, 50$10000 \mathrm{ppm} \mathrm{Zn}, 20-10000 \mathrm{ppm} \mathrm{Pb}, 5-<500 \mathrm{ppm} \mathrm{Cu},<0.1-2.1 \mathrm{ppm}$ $\mathrm{Ag}$, and 0.3 to $2.0 \mathrm{wt} . \% \mathrm{~F}$.

Geochemical data support petrographic observations that there is a spectrum of alteration types. $\mathrm{Fe}_{2} \mathrm{O}_{3}, \mathrm{Mn}$ and $\mathrm{MgO}$ enrichment correspond to chlorite and/or Fe muscovite alteration whereas $\mathrm{Na}_{2} \mathrm{O}$ and $\mathrm{K}_{2} \mathrm{O}$ depletion resulted in $\mathrm{Al}_{2} \mathrm{O}_{3}$ enrichment until topaz became stable. $\mathrm{CaO}$ was remobilized in the greisen environment, but erratically deposited as fluorite. The distribution of trace elements reflects their relative mobility during greisenization, with high field strength elements $(\mathrm{Zr}$ and $\mathrm{Ti})$ the most immobile and the lithophile and chalcophile elements the most mobile.

Mineralization associated with the fine-grained Mount Pleasant granite and the porphyritic Eastern Saint George granite are similar to that develped in association with the True Hill granitc porphyry. The present distribution of the mineralization and the associated alteration throughout the area seems to be dominantly controlled by the depth of emplacement and the competency (structural preparation) of the enclosing rocks.

\section{ACKNOWLEDGEMENTS}

The first authour is indebted to Billiton Canada Ltd. (presently FinNeth) for their generous financial support and would also like to thank them for access to their information. We are also grateful to R. Wallis of FinNeth for allowing us to publish our findings. J. Atkinson recommended the project and Dr. A.L. McAllister supervised the M.Sc. research of D.L. while at U.N.B. We are also grateful to A.A. Ruitenberg, M. McLeod, E. MacLellan, and R.P. Taylor for many helpful discussions. D.L. would like to thank S. Townsend, J. Vahtra and Dr. H. DeSouza for their technical assistance and moral support during graduate studies at U.N.B.. Thanks also to J. Loop (University of Ottawa). We also thank the reviewers, particularly L. Fyffe, for their patience and valuable suggestions.

ABBEY, S. 1983. Studies in "Standard Samples" of Silicate Rocks and Minerals 1969-1982. Geological Survey of Canada, Paper 83-15. $114 \mathrm{p}$.

BAUMANN, L. 1970. Tin Deposits of the Erzgebirge. Institute of Mining and Metallurgy Transactions, 79, pp. B68-75.

BURNHAM, C.W. 1979. Magmas and Hydrothermal Fluids. In Geochemistry of Hydrothermal Ore Deposits, 2nd Edition. Edited by H.L. Barnes. John Wiley and Sons Lid., New York, pp. 71-136.

BURNHAM, C.W. and OHMOTO, H. 1980. Late stage processes of Felsic Magmatism. Edited by S. Ishihara and S. Takenouchi. Mining Geology, Special Issue No. 8, Society of Mining Geologists, Japan, pp. 1-11.

BURT, D.M. 1981. Acidity-Salinity Diagrams - Application to Greisen and Porphyry Deposits. Economic Geology, 76, pp. 832-843.

BUTT, K.A. 1976. Genesis of granitic stocks in southwestem New Brunswick. Unpublished Ph.D. thesis, University of New Brun- 
swick, 235 p.

CHATTERJEE, A.K., STRONG, D.F., and MUECKE, G.K. 1983. A multivariate approach to geochemical distinction between tinspecialized granites of southern Nova Scotia. Canadian Journal of Earth Sciences, 20, pp. 420-430.

CHERRY, M.E. 1976. The petrogenesis of granites in the Saint George batholith, southwestern New Brunswick. Unpublished Ph.D. thesis, University of New Brunswick, 242 p.

CHERRY, M.E. and TREMBATH, L.T. 1978. The Pressure Quench Formation of Rapakivi Texture. Contributions to Mineralogy and Petrology, 68, pp. 1-6.

COLLINS, W.J., BEAMS, S.D., WHITE, A.J.R., and CHAPPELL, B.W. 1982. Nature and Origin of A-Type granites with particular reference to southeastem Australia. Contributions to Mineralogy and Petrology, 80, pp. 189-200.

CULLERS, R.L. and GRAF, J.L. 1984. Rare Earth Elements in Igneous Rocks of the Continental Crust: Intermediate and Silicic RocksOre Petrogenesis. In Rare Earth Element Geochemistry. Edited by P. Henderson. Developments in Geochemistry, 2, Elsevier, New York, pp. 275-316.

DAGGER, G.W. 1972. Genesis of the Mount Pleasant tungstenmolybdenum deposit, New Brunswick. Institute of Mining and Metallurgy. Transactions Sec. B, 81, Bulletin 786, pp. 73-102.

DAVIS, W.J. and WILLIAMS-JONES, A.E. 1985. A fluid inclusion study of the porphyry greisen, tungsten-molybdenum deposits at Mount Pleasant, New Brunswick, Canada. Mineralium Deposita, 20, pp. 94-101.

DRUMMOND, S.E. and OHMOTO, H. 1985. Chemical Evolution and Mineral Deposition in Boiling Hydrothermal Systems. Economic Geology, 80, pp. 126-147.

EKWERE, S.J. 1985. Li, $\mathrm{F}$ and $\mathrm{Rb}$ contents and $\mathrm{Ba} / \mathrm{Rb}$ and $\mathrm{Rb} / \mathrm{Sr}$ ratios as indicators of post-magmatic alteration and mineralization in the granitic rocks of the Banke and Ririwai Younger Granite complexes, Northem Nigeria. Mineralium Deposita, 20, pp. 89-93.

EL BOUSEILY, A. and EL SOKKARY, A. 1975. The Relation between $\mathrm{Rb}, \mathrm{Ba}$ and $\mathrm{Sr}$ in Granitic Rocks. Chemical Geology, 16, pp. 207-219.

FLYNN, R.T. and BURNHAM, C.W. 1978. An experimental determination of Rare Earth Partition Coefficients between a chloride containing vapour phase and Silicate Melts. Geochimica et Cosmochimica Acta, 42, pp. 685-701.

FYFFE, L.R., PAJARI, G.E., and CORMIER, R.F. 1981. Rb-Sr Geochronology of New Brunswick. Geological Society of America Abstracts, 13, p. 133.

HOLLAND, H.D. and MALININ, S.D. 1979. The Solubility and Occurrence of Non-Ore Minerals. In Geochemistry of Hydrothermal Ore Deposits. Edited by H.L. Bames. John Wiley and Sons Lid., New York, pp. 461-508.

JAMES, R.S. and HAMILTON, D.L. 1969. Phase relations in the system $\mathrm{NaAlSi}_{3} \mathrm{O}_{8}-\mathrm{KAlSi}_{3} \mathrm{O}_{8}-\mathrm{CaAl}_{2} \mathrm{Si}_{2} \mathrm{O}_{3}-\mathrm{SiO}_{2}$ at 1 kilobar water vapour pressure. Contributions to Mineralogy and Petrol- ogy, 21, pp. 111-141.

KOOIMAN, G.J.A., McLEOD, M.J., and SINCLAIR, W.D. 1986. Porphyry Tungsten-Molybdenum Orebodies, Polymetallic Veins and Replacement Bodies and Tin-bearing Greisen Zones in the Fire Tower Zone, Mount Pleasant, New Brunswick. Economic Geology, 81, pp. 1356-1373.

LENTZ, D.R. 1986. Geology and Depositional conditions of tin lodes at True Hill, New Brunswick. Unpublished M.Sc. thesis, University of New Brunswick, 280 p.

LUND, N. 1981. Mineralogy and Alteration at True Hill, southem New Brunswick. Unpublished B.Sc. thesis, University of New Brun- swick, 113 p.

MANNING, D.A.C. 1981. The effect of fluorine on liquidus phase relations in the system Qz-Ab-Or with excess water at lkb. Contributions to Mineralogy and Petrology, 76, pp. 206-215.

MacLELLAN, E. 1983. Victoria Lake prospect. New Brunswick Department of Natural Resources, Mineral Resources Division, Assessment File 472945.

McCUTCHEON, S.R. and RUITENBERG, A.A. 1983. Geology of the Eastern Saint George Batholith. Geological Surveys Branch, New Brunswick, Department of Natural Resources, Plate 83-9.

McLEOD, J.M., TAYLOR, R.P., and LUX, D.R. In press. Geology, ${ }^{40} \mathrm{Ar} /{ }^{39} \mathrm{Ar}$ Geochronology and Sn-W-Mo-bearing Sheeted veins on the Mount Douglas Granite, SW New Brunswick. Canadian Institute of Mining and Metallurgy Bulletin, 81, pp. 70-77.

- 1988. Sn-W mineralization and the age of the Mount Douglas granite, southwestern New Brunswick. Geological Association of Canada/ Mineralogical Association of Canada, Program with Abstracts, 13, p. A83.

NEIVA, A.M.R. 1984. Geochemistry of tin-bearing Granitic rocks. Chemical Geology, 43, pp. 241-256.

PARRISH, I.S. and TULLY, J.V. 1978. Porphyry tungsten zones at Mount Pleasant, New Brunswick. Canadian Institute of Mining and Metallurgy Bulletin, June, pp. 93-100.

PEARCE, J.A., HARRIS, N.B.W., and TINDLE, A. 1984. Trace Element Discrimination Diagrams for the Tectonic Determination of Granitic Rocks. Joumal of Petrology, 25, pp. 956-983.

POULIOT, G., BARONDEAU, B., SAUVE, P., and DAVIS, M. 1978. Distribution of alteration minerals and metals in the Fire Tower Zone at Brunswick Tin Mines Ltd., Mt. Pleasant area, N.B. Canadian Mineralogist, 16, pp. 223-237.

RUTTENBERG, A.A. 1972. Metallization episodes related to tectonic evolution, Rolling Dam and Mascarene-Nerepis belts, N.B. Economic Geology, 67, pp. 434-444.

RUITENBERG, A.A. and FYFFE, L.R. 1982. Mineral Deposits associated with the granitoid intrusions and subvolcanic stocks in New Brunswick and their relation to Appalachian tectonic evolution. Canadian Institute of Mining And Metallurgy Bulletin, 75, pp. 83-97.

RUTTENBERG, A.A. and McCUTCHEON, S.R. 1982. Acadian and Hercynian Structural Evolution of Southem New Brunswick. In Major Structural Zones and Faults of the Northem Appalachians. Edited by P. St.-Julian and J. Béland. Geological Association of Canada, Special Paper 24, pp. 131-148.

- 1985. Tungsten. Molybdenum and Tin Deposits in New Brunswick. GAC-MAC Field Excursion, 13, 33 p.

RUTTENBERG, A.A., McCUTCHEON, S.R., VENUGOPAL, D.V., and PIERCE, G.A. 1977. Mineralization associated with postAcadian Tectonism in Southem New Brunswick. Geoscience Canada, 4, pp. 13-22.

SHCHERBA, G.N. 1970. Greisens. IntemationalGeology Review, 12, pp. 114-150.

TAYLOR, R.G. 1979. Geology of Tin Deposits. Elsevier Publishing Company, New York, 543 p.

TAYLOR, R.P., SINCLAIR, W.D., and LUTES, G.G. 1985. Geochemical and Isotopic Characterization of granites Related to W. Sn-Mo mineralization in the Mount Pleasant Area, New Brunswick. In Granite Related Mineral Deposits. Edited by R.P. Taylor and D.F. Strong. Canadian Institute of Mining and Metallurgy, pp. 265-273.

VARLAMOFF, N. 1978. Classification and spatio-temporal distribution of tin and associated mineral deposits. In Metallization Associated with Acid Magmatism. Edited by M. Stemprok, L. 
Bumol and G. Tischendorf. Ustredni Ustav. Geologicky, Praha, 3, pp. 139-158.

WHITE, W.H., BOOKSTROM, A.A., KAMILLI, R.J., GANGSTER,
M.W., SMITH, R.R., RANTA, D.E., and STEINNGER, R.C. 1981. Character and Origin of Climax-type molybdenum deposits. Economic Geology, 75th Anniversary Volume, pp. 270-316. 